\title{
Review \\ Synthesis of Nitroarenes by Oxidation of Aryl Amines
}

\author{
Antonella Capperucci and Damiano Tanini * \\ Dipartimento di Chimica 'Ugo Schiff', University of Florence, Via della Lastruccia 3-13, \\ 50019 Sesto Fiorentino (FI), Italy; antonella.capperucci@unifi.it \\ * Correspondence: damiano.tanini@unifi.it; Tel.: +39-055-4573552
}

check for updates

Citation: Capperucci, A.; Tanini, D. Synthesis of Nitroarenes by Oxidation of Aryl Amines. Chemistry 2022, 4, 77-97. https://doi.org/ $10.3390 /$ chemistry 4010007

Academic Editor: Edwin Charles Constable, Tomas Ramirez Reina, Peter J. Rutledge and Luis R. Domingo

Received: 17 January 2022

Accepted: 2 February 2022

Published: 7 February 2022

Publisher's Note: MDPI stays neutral with regard to jurisdictional claims in published maps and institutional affiliations.

Copyright: (c) 2022 by the authors. Licensee MDPI, Basel, Switzerland. This article is an open access article distributed under the terms and conditions of the Creative Commons Attribution (CC BY) license (https:// creativecommons.org/licenses/by/ $4.0 /)$.

\begin{abstract}
Nitro compounds are an important class of organic molecules with broad application in organic synthesis, medicinal chemistry, and materials science. Among the variety of methodologies available for their synthesis, the direct oxidation of primary amines represents an attractive alternative route. Efforts towards the development of oxidative procedures for the synthesis of nitro derivatives have spanned over the past decades, leading to a wide variety of protocols for the selective oxidative conversion of amines to nitro derivatives. Methods for the synthesis of nitroarenes via oxidation of aryl amines, with particular emphasis on recent advances in the field, are summarised in this review.
\end{abstract}

Keywords: nitro compounds; nitroarenes; oxidation; peroxyacids; sodium perborate; hydrogen peroxide; dimethyldioxirane; tert-butyl hydroperoxide; amines; anilines

\section{Introduction}

Nitro compounds occupy an important position in organic chemistry. Owing to their easy availability and their potential to be converted into a broad range of functional groups, nitro derivatives are widely employed in organic synthesis [1]. Nitroarenes are used as versatile building blocks for the synthesis of relevant chemicals, including pharmaceuticals [2,3], dyes [4,5], materials [6], and perfumes [7]. A number of nitro-containing compounds such as nitroxoline [8], nitrofural [9], nitrofurantoin [10,11], and chloramphenicol [12] are market-available drugs. Nitro derivatives also play a significant role in the development of mechanistic concepts [13]. A great deal of attention has thus been devoted to the development of practical and convenient methodologies for their synthesis. The synthesis of aromatic nitro compounds was reviewed almost ten years ago by Yan and Yang [14]. The "classical" route towards nitroarenes-relying on the electrophilic nitration of aromatic derivatives-is arguably one of the most extensively studied organic transformations. The harsh reaction conditions, along with the imperfect functional group tolerance and the poor regioselectivity, represent the main drawbacks of this route. Many aromatic nitro derivatives remain difficult to synthesise through such a route [15]. A broad range of alternative nitration reagents and methodologies-including transition-metalcatalysed ipso-nitration methodologies-have emerged as powerful tools for the synthesis of nitroarenes $[14,16]$.

In this context, the direct oxidation of primary amines enables issues related to regioselectivity to be overcome and provides an attractive, alternative, and fascinating route for the synthesis of nitro derivatives. Several methods for the oxidative transformation of primary amines to nitro compounds have been developed over the past decades, and particular attention has been devoted to the investigation of environmentally benign protocols. One of the issues that should be considered when investigating the oxidation of amines is related to the selectivity of the process. For example, considering the oxidation of aniline to nitrobenzene, azoxybenzene 2 and nitrosobenzene 3 represent typical by-products that can be formed alongside the desired nitroarene 1a (Scheme 1). 


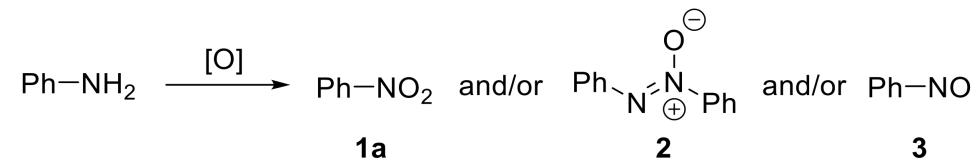

Scheme 1. Possible oxidation products of aniline.

This review focuses on oxidation-based methodologies for the conversion of aryl amines to nitroarenes. The scope and limitations of currently available procedures are presented with particular emphasis on mechanistic aspects.

\section{Oxidation with Peroxyacids}

Peroxyacids have been largely employed as oxidising agents for the conversion of amines into the corresponding nitro derivatives. A number of methods relying on the reactivity of peroxyacids have consequently been reported. Problems related to the selectivity of oxidation-based routes for the synthesis of nitroarenes $\mathbf{1}$ were already documented at the beginning of the last century. For example, the reaction of aniline with peracetic acid was described as providing only an 11\% yield of nitrobenzene 1a; azoxybenzene 2 represented the main reaction product $[17,18]$. In 1957, Emmons reported the synthesis of nitro derivatives 1a-f via oxidation of amines with anhydrous solutions of peracetic acid, freshly generated from acetic acid and hydrogen peroxide in the presence of catalytic amounts of sulfuric acid (Scheme 2) [19]. The reaction enabled the oxidation of a series of differently substituted anilines with good yield, although variable amounts of the corresponding azoxyarenes were detected. Notably, trifluoroperacetic acid led to higher yields and could also be used for the oxidation of weakly basic amines such as nitroaniline [20]. A limited number of nitroalkanes were also achieved upon oxidation of aliphatic amines with peracetic acid [19]. Oxidation of aniline to nitrobenzene has also been achieved by using the hexafluoroacetone-hydrogen peroxide complex, which behaves as an effective oxidising agent [21].
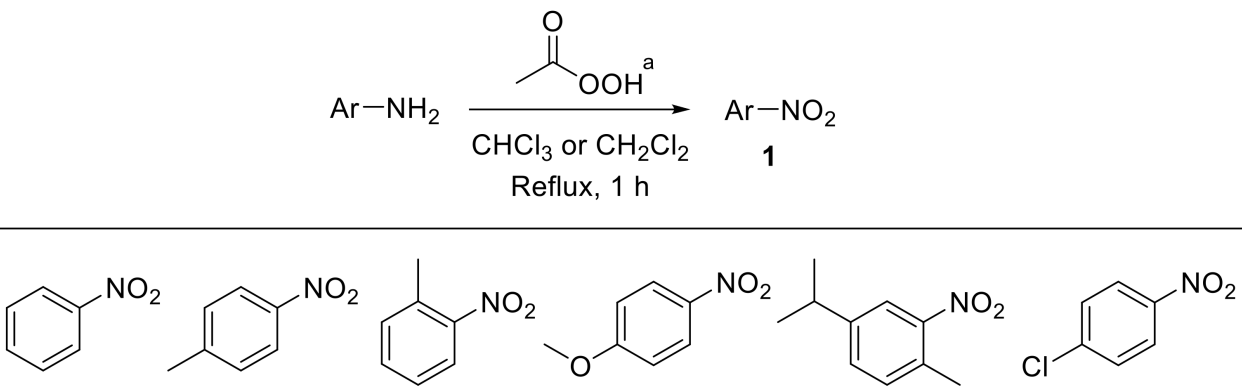

$\begin{array}{llllll}1 \text { a }, 83 \% & 1 \text { b, } 72 \% & \text { 1c, } 70 \% & 1 d, 82 \% & 1 \text { e, } 72 \% & 1 \text { f, } 62 \%\end{array}$

Scheme 2. Synthesis of nitroarenes via oxidation of anilines with peracetic acid. a Anhydrous peracetic acid was generated in situ upon reaction of acetic anhydride with $90 \%$ hydrogen peroxide under $\mathrm{H}_{2} \mathrm{SO}_{4}$ catalysis.

Several $m$-CPBA-based procedures for the conversion of a variety of amines into the corresponding nitro derivatives have been developed over the past decades. Such routes have been efficiently applied to aliphatic [22], steroidal [23], diamondoid [24], and aromatic amines [25]. For example, Liu et al. reported the synthesis of a broad range of variously substituted nitroarenes 1 through the oxidation of anilines with $m$-CPBA in 1,2-dichloroethane. This approach was amenable to both electron-rich and electron-poor substrates and proved to be scarcely sensitive to steric effects (Scheme 3) [25]. 


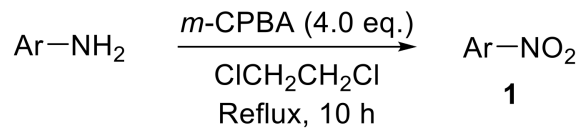

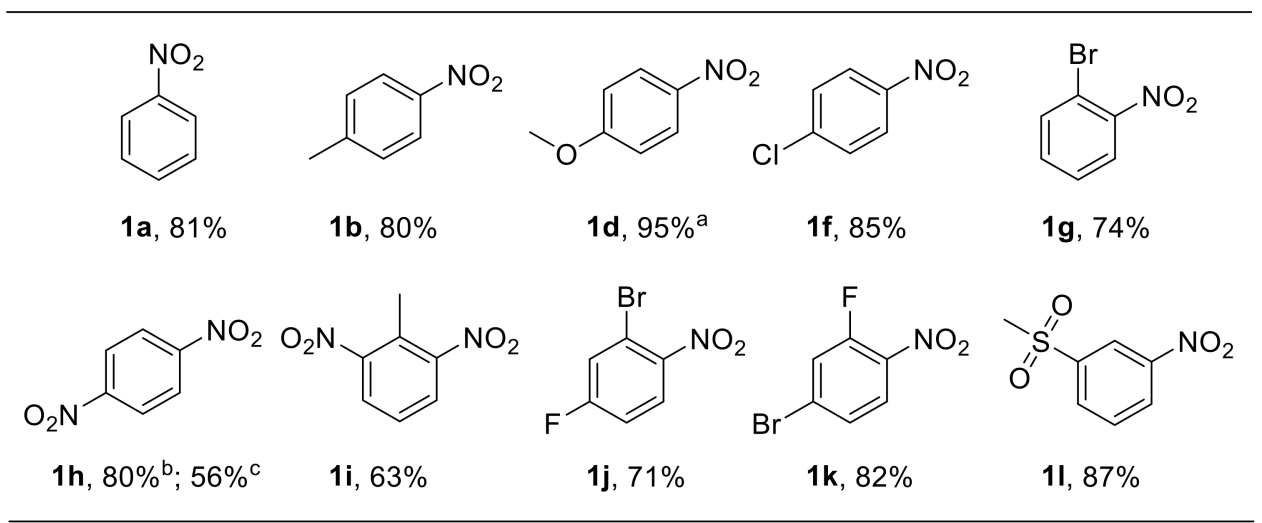

Scheme 3. Oxidation of anilines to nitroarenes with $m$-CPBA ( $m$-chloroperbenzoic acid) (selected examples). ${ }^{a}$ The reaction was performed at room temperature. ${ }^{b}$ Prepared through oxidation of 4-nitroaniline. ${ }^{\mathrm{c}}$ Prepared through oxidation of 1,4-diaminobenzene with 8.0 eq of $m$-CPBA.

A convenient 1-butyl-3-methyl-imidazolium-phosphotungstate-catalysed procedure for the oxidation of anilines with $m$-CPBA was recently reported by Meenakshi et al. [26]. The combination of ionic liquids (ILs) and polyoxometalates (POMs) provides hybrid materials fixing Keggin ions in the solid state and retaining the properties of both organic cations of ILs and inorganic anions of POMs. Such immobilised polyoxometalate hybrid materials have been widely employed in heterogeneous catalysis [27,28]. In this context, Meenakshi et al. investigated the catalytic performances of various Keggin-ion-based hybrid materials in the oxidation of aryl amines. 1-Butyl-3-methyl imidazolium phosphotungstate hybrid materials [bmim $]_{3}\left[\mathrm{PW}_{12} \mathrm{O}_{40}\right]$, synthesised from 1-butyl-3-methyl imidazolium bromide (bmimBr) and $\mathrm{H}_{3} \mathrm{PW}_{12} \mathrm{O}_{40} \cdot n \mathrm{H}_{2} \mathrm{O}$, exhibited remarkable catalytic properties for the oxidative conversion of anilines into nitroarenes using $m$-CPBA in acetonitrile at $85{ }^{\circ} \mathrm{C}$ for $2 \mathrm{~h}$ (Scheme 4) [26]. The scope of the reaction proved to be broad, encompassing both electron-rich and electron-poor anilines, which could be converted into the corresponding nitroarenes with high selectivity and with only small amounts of azoxybenzenes being formed as side products. An additional interesting feature of this protocol was the possibility of easily recovering and reusing the catalyst three times, without significant loss of catalytic activity.

$$
\mathrm{Ar}-\mathrm{NH}_{2}+m \text {-CPBA } \stackrel{[\mathrm{bmim}]_{3}\left[\mathrm{PW}_{12} \mathrm{O}_{40}\right]}{\stackrel{\mathrm{MeCN}}{\longrightarrow}} \quad \mathrm{Ar}-\mathrm{NO}_{2}
$$

$1 \mathrm{~b},(87 \%)^{\mathrm{a}}$

Scheme 4. Oxidation of anilines to nitroarenes with $m$-CPBA catalysed by $[\mathrm{bmim}]_{3}\left[\mathrm{PW}_{12} \mathrm{O}_{40}\right]$ (selected examples). ${ }^{\text {a }}$ Selectivity for nitroarenes over azoxy- and diazo-arenes is reported in parentheses; selectivity was determined by GC-MS.

The use of nonanebis (peroxoic acid) as an oxidising agent towards anilines was also investigated [29]. Notably, such a diperoxy acid was proved to behave as an effective reagent for the conversion of aryl amines into nitroarenes under metal-catalyst-free 
conditions, and it exhibited significantly higher reactivity with respect to monoperoxy acids. The reaction, performed in acetonitrile at $50{ }^{\circ} \mathrm{C}$, exhibited a broad scope, enabling the oxidation of a broad range of substituted anilines to provide the corresponding nitroarenes $\mathbf{1 a}, \mathbf{b}, \mathbf{m}-\mathbf{r}$ with good yield (Scheme 5). An interesting feature of this protocol is related to the reactivity of ortho-substituted anilines. Indeed, amines bearing hydrogen(s) on a heteroatom at the ortho position smoothly undergo oxidation, affording the corresponding nitro derivatives. On the other hand, when an $X-H$ moiety $(X=N H, N R, O)$ is not present at the ortho position, the oxidation of the amino functionality does not occur. Thus, while 2aminophenol was efficiently converted into 2-nitrophenol 1r upon reaction with nonanebis (peroxoic acid), 2-methoxyaniline proved to be unreactive under the same reaction conditions. Similarly, $N^{1}, N^{1}$-dimethylbenzene-1,2-diamine and 2-nitroaniline failed to undergo oxidation (Scheme 4, unreactive substrates). On the basis of these results, ortho-substituted nitroarenes $\mathbf{1 r}-\mathbf{u}$ were efficiently achieved via oxidation of the corresponding anilines. Notably, the regioselectivity and chemoselectivity of the process allowed the preparation of 2-nitroaniline 1s from 1,2-diaminobenzene with excellent yield. The proposed explanation of the observed steric-hindrance-induced selectivity relies on the presence of hydrogen bonding interactions involving the ortho- $\mathrm{XH}$ group and the carbonyl oxygen of the diperoxy acid, which facilitate the oxidation reaction (Scheme 6) [29].

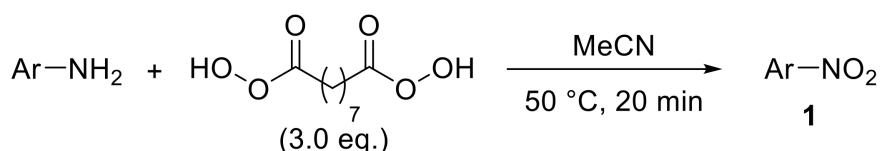<smiles>COc1cccc([N+](=O)[O-])c1</smiles>

Unreactive substrates

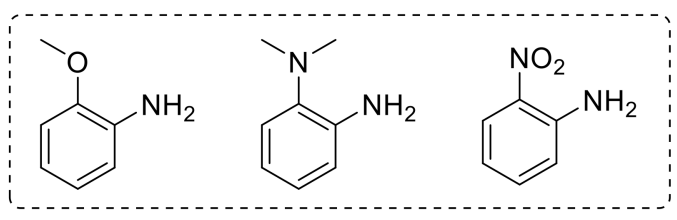

Scheme 5. Selected examples of oxidation of anilines with nonanebis (peroxoic acid) to give nitroarenes.

Additionally, such a steric-hindrance-induced regioselective and chemoselective oxidative approach was also employed for the synthesis of commercially important molecules such as $\mathbf{1 v}$ (dichloran, a fungicide) and 1w (used as an azo dye for nonlinear optics-NLO) by selective oxidation of the less hindered amino group of the corresponding diamine derivative (Scheme 5). 


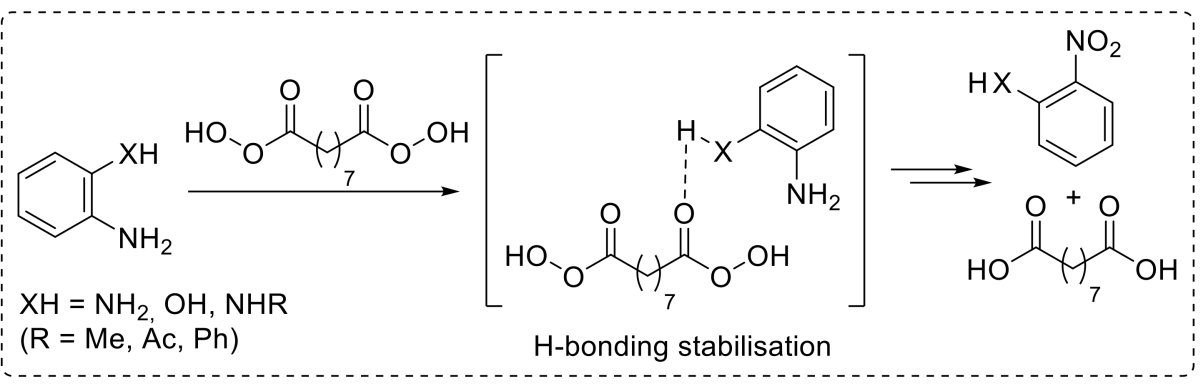

Scheme 6. Hydrogen bonding between $\mathrm{H}$ atom on the ortho- $\mathrm{XH}$ substituent and the carbonyl oxygen of the diperoxy acid, reasonably accounting for the steric-hindrance-induced regioselective oxidation of anilines with nonanebis (peroxoic acid).

\section{Oxidation with Tert-butyl Hydroperoxide}

A number of metal-catalysed approaches for the oxidation of amines to nitro derivatives with tert-butyl hydroperoxide (TBHP) have been developed. The oxidation of aromatic amines using hierarchical micro-meso-macroporous CuAlPO-5 as the catalyst was reported by Ke et al. [30] Aluminophosphate zeolites are porous materials characterised by high thermal stability. Aluminium and/or phosphorus atoms in the aluminophosphate framework (AlPO-n) can be replaced with metal ions providing metal-doped aluminophosphate (MAlPO-n) materials. CuAlPO-5 zeolite was hydrothermally synthesised using a silane surfactant and 1,1,3,3-tetramethylguanidine as the structure-directing agent (SDA). The calcined CuAlPO-5 zeolite showed remarkable catalytic properties for the oxidation of bulky arylamines to the corresponding nitroarenes, using TBHP as the oxidant. The reaction scope was found to be broad, enabling the oxidation of anilines bearing substituents at different positions of the aromatic ring (Scheme 7). Notably, the CuAlPO-5 catalyst could be efficiently recovered and reused up to five times, enabling the oxidation of 4-bromoaniline to the corresponding nitroarene with excellent conversion and selectivity over the other oxidation products [30].

$$
\mathrm{Ar}-\mathrm{NH}_{2}+\mathrm{TBHP} \underset{\mathrm{MeCN}}{\stackrel{\mathrm{CuAIPO}-5}{\longrightarrow}} \mathrm{Ar}-\mathrm{NO}_{2}
$$

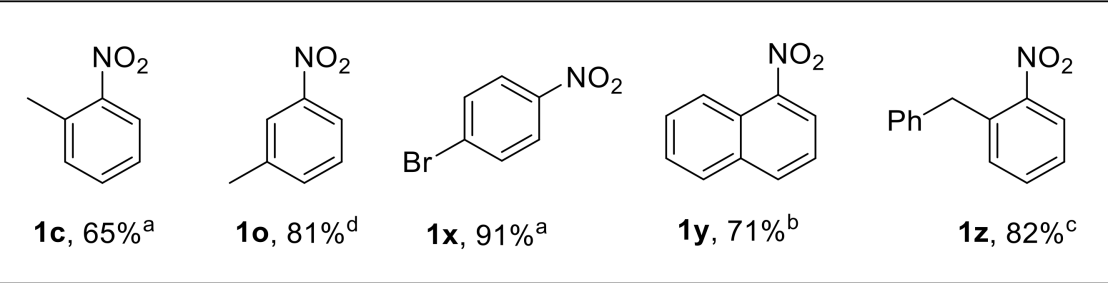

Scheme 7. CuAlPO-5-catalysed oxidation of arylamines with TBHP (selected examples). a Selectivity: $100 \%{ }^{\text {b }}$ selectivity: $72 \%{ }^{c}{ }^{\mathrm{c}}$ selectivity: $95 \%{ }^{\mathrm{d}}$ selectivity: $93 \%$.

The use of chromium silicalite-2 (CrS-2) as a stable and recyclable catalyst for the direct oxidation of primary amines with TBHP was also described [31]. The chromium-containing medium-pore zeolite CrS-2 ( $\mathrm{Si}: \mathrm{Cr}>140: 1$ ) efficiently catalyses the oxidation of a wide range of amines providing nitro derivatives with good yield. Notably, this heterogeneous catalyst enabled the oxidation of both aromatic and aliphatic amines to nitroarenes and nitroalkanes (Scheme 8). On the other hand, benzylamine provided benzaldoxime under the same reaction conditions. From the mechanistic point of view, the oxochromium (V) species of the zeolite framework are believed to promote the oxidation of the amine to the nitro derivative. Control experiments highlighted that such oxidation reasonably proceeds through hydroxylamine and nitroso intermediates [31]. 


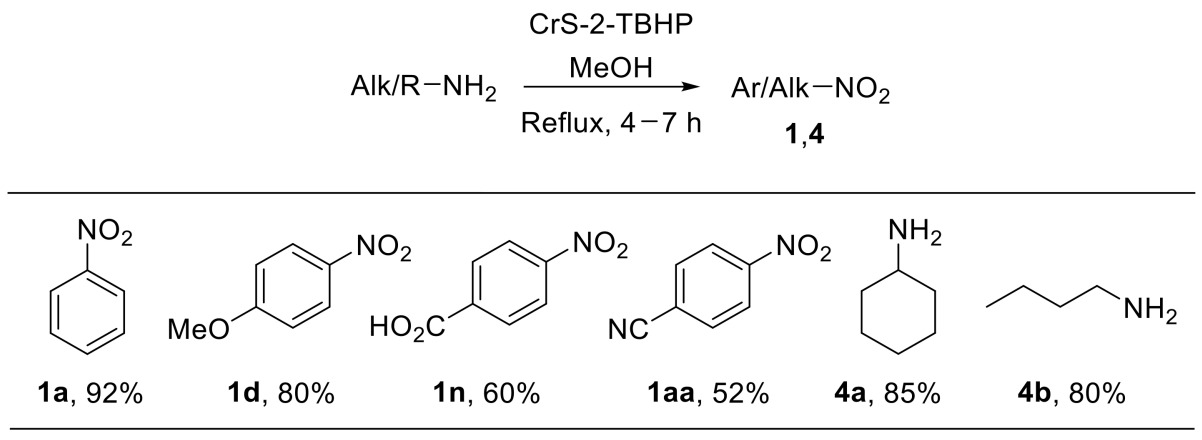

Scheme 8. Chromium silicalite-2 (CrS-2)-catalysed oxidation of amines with TBHP.

A rhodium-catalysed approach for the oxidation of substituted anilines with tert-butyl hydroperoxide (TBHP) was developed by Doyle et al. tert-Butylperoxy radicals, which behave as effective oxidants for phenols and anilines, can be easily generated from TBHP under dirhodium caprolactamate, $\mathrm{Rh}_{2}(\mathrm{cap})_{4}$, catalysis. Anilines are preferentially oxidised to nitroarenes, although variable amounts of dienones 5 , formed upon hydrolysis of the corresponding dienimines, were detected (Scheme 9). Anilines bearing electron-donating groups provided the corresponding nitro derivatives with higher yields $(\mathbf{1} \mathbf{b}, \mathbf{d})$. On the other hand, both aromatic substituents in the ortho position $(\mathbf{1} \mathbf{a}, \mathbf{b})$ and electron-withdrawing groups in the para position $(\mathbf{1 f}, \mathbf{h})$ led to significantly reduced yields. The reaction mechanism reasonably proceeds through nitroso compounds; the formation of $\mathbf{5}$ suggests that, similarly to the related phenolic oxidation, the oxidation of anilines involves the hydrogen atom abstraction from the amino group followed by trapping by the peroxy radical at the nitrogen or at the para position. Notably, the application of this methodology to aliphatic primary amines enabled their conversion into carbonyl derivatives via oxidative removal of the amino group [32].

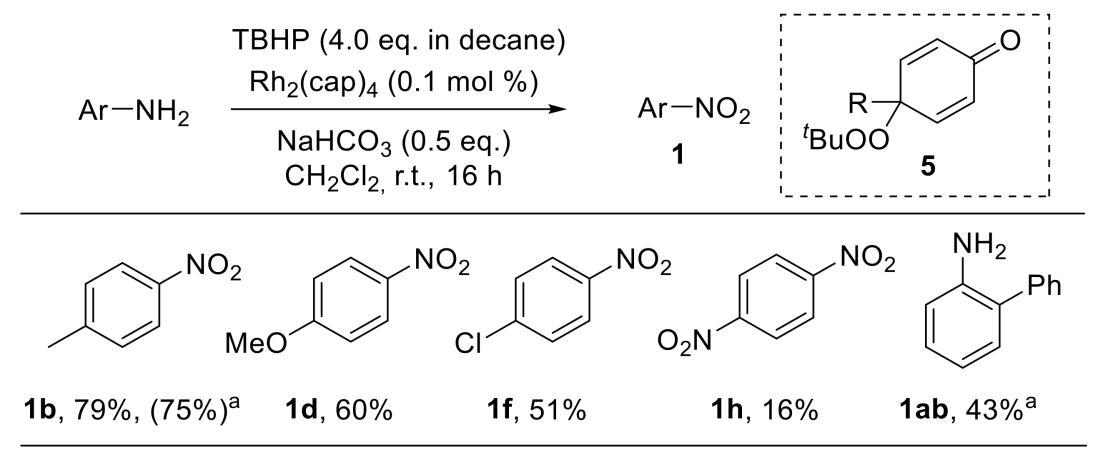

Scheme 9. Rhodium-catalysed oxidation of anilines to nitroarenes. ${ }^{a}$ The reaction was performed using $1.0 \mathrm{~mol} \%$ of $\mathrm{Rh}_{2}(\text { cap })_{4}$ and T-HYDRO (70\% tert-butyl hydroperoxide in water, $\left.4.0 \mathrm{eq}\right)$ at $40{ }^{\circ} \mathrm{C}$ for $20 \mathrm{~min}$.

A metallo-porphyrins-catalysed protocol for the oxidation of anilines to nitroarenes with TBHP was also developed. Both iron (III) and manganese (III) tetraaryl porphyrins were employed as catalysts in the presence of various axial ligands including imidazole, 1-methylimidazole, 2-methylimidazole, and 4-tert-butylpyridine. The oxidation was conducted using TBHP in dichloromethane at room temperature. While the imidazole series gave similar results in terms of reaction yield, the more weakly coordinating 4-tert-butylpyridine proved to be less efficient. Additionally, the oxidation reaction was demonstrated to be less effective using Mn (III) complexes with respect to related Fe (III) complexes (Scheme 10) [33]. 

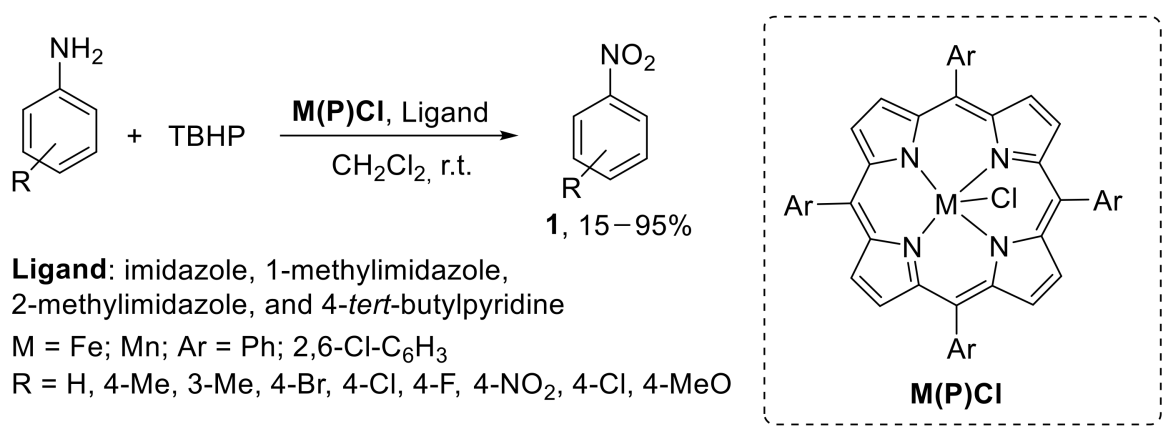

Scheme 10. Metallo-porphyrins-catalysed oxidation of anilines to nitroarenes with TBHP. Reaction time depends on the nature of both the substrate and the catalyst.

A zirconium-catalysed approach for the oxidative conversion of aryl amines to nitroarenes has also been described. A broad array of differently substituted anilines react with TBHP in the presence of catalytic amounts of $\mathrm{Zr}\left(\mathrm{O}^{t} \mathrm{Bu}\right)_{4}$ to generally afford good yields of the corresponding nitrobenzenes. The reaction was also extended to the oxidation of aminopyridines, which provided the related nitropyridines at lower yields (Scheme 11) [34].

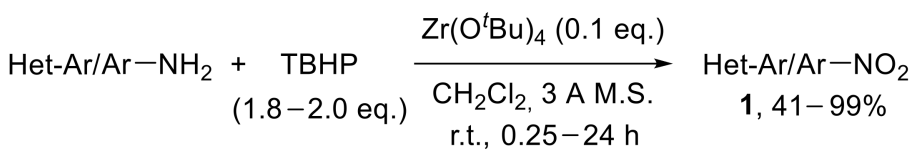

$$
\begin{aligned}
& \begin{array}{l}
\mathrm{R}^{1}-\mathrm{R}^{5}: \mathrm{H} ;{ }^{i} \mathrm{Pr} ; \mathrm{CO}_{2} \mathrm{Et} ; \mathrm{N}_{2} \mathrm{C}_{6} \mathrm{H}_{5} ; \\
\mathrm{AlkO} ; \mathrm{Cl} ; \mathrm{CN} ; 4-\mathrm{NH}_{2}-\mathrm{C}_{6} \mathrm{H}_{4}
\end{array}
\end{aligned}
$$

Scheme 11. Zirconium-catalysed oxidation of anilines to nitroarenes with TBHP.

Besides metal-catalysed procedures, a selective approach for the conversion of aryl amines to nitro derivatives using TBHP in the presence of catalytic amounts of potassium iodide was also developed. The reaction could be successfully applied both to electron-rich and electron-poor substrates, affording good yields of the corresponding nitroarenes [35].

\section{Oxidation with Hydrogen Peroxide}

Owing to their versatility, metal-catalysed routes for the oxidative conversion of amines to nitro derivatives with hydrogen peroxide have attracted considerable interest. Generally, the recycling performances of used catalysts were also investigated.

Dewkar et al. reported the use of a novel hydrated titanium matrix as a heterogeneous catalyst for the oxidation of primary amines using hydrogen peroxide. While aliphatic primary amines with $\alpha-\mathrm{CH}$ bonds provided oximes along with the corresponding ketone, anilines were converted into nitroarenes [36]. This protocol proved to be amenable both to electron-poor and electron-rich anilines, giving the corresponding nitro compounds with high selectivity. The formation of variable amounts (0.37-9.01\%) of azoxyarenes and nitrosoarenes was also observed. Notably, the catalyst could be easily recovered and successfully reused. The proposed catalytic cycle is reported in Figure 1. The radical anion 7, generated from 6 and $\mathrm{H}_{2} \mathrm{O}_{2}$, abstracts a hydrogen atom from the amine, affording a transient $\mathrm{RNH}^{\bullet}$ radical species $\mathbf{8}$. Species $\mathbf{8}$ is then oxidised to the nitroso derivative $\mathbf{9}$, which undergoes further oxidation to give the nitro compound $\mathbf{1}$ and regenerate the catalyst 6 . 


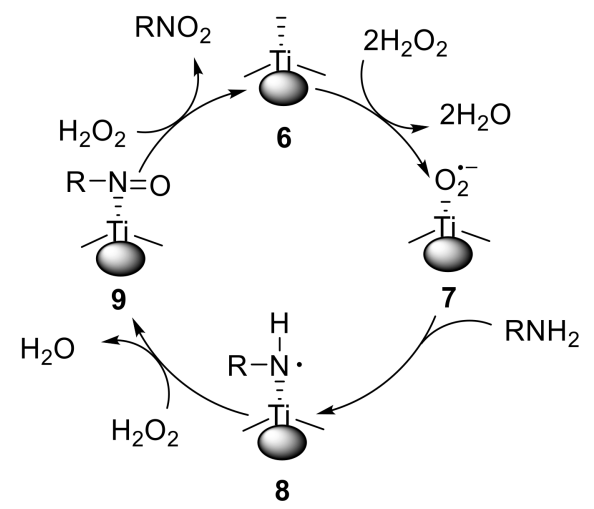

Figure 1. Proposed catalytic cycle for the oxidation of amines.

The use of calcium tungstate as a convenient and recoverable catalyst for the oxidation of organic compounds with $\mathrm{H}_{2} \mathrm{O}_{2}$ was reported by Kyler et al. An active homogeneous solution of pertungstate species, formed upon treatment of $\mathrm{CaWO}_{4}$ with $\mathrm{H}_{2} \mathrm{O}_{2}$ and stabilised with 9,10-phenanthroline, can be employed as an efficient catalyst for the oxidation of amines, alcohols, alkenes, and sulfides. This methodology was applied to the synthesis of nitrobenzene, 4-nitrotoluene, and 3-nitroisoxazole with 95\%, 93\%, and 85\% yield, respectively. Notably, the catalyst could be easily recovered from the aqueous phase by filtration; no loss of catalytic activity was found after five cycles of oxidation. The approach was demonstrated to be easily scalable and could be used for the oxidation of $p$-toluidine at a kilogram scale leading to 4-nitrotoluene with $92 \%$ yield, with a $>99 \%$ recovery of the catalyst [37].

Heteropolyoxometalates have also been employed as catalysts for the oxidative conversion of amines into nitro derivatives. Ishii et al. reported that anilines react with hydrogen peroxide in the presence of peroxotungstophosphate, which can be prepared upon treatment of tungstophosphoric acid with $\mathrm{H}_{2} \mathrm{O}_{2}$ and cetylpyridinium chloride in water. Notably, the reaction temperature proved to be crucial for the selectivity of the process; indeed, while high temperatures (i.e., refluxing chloroform) provided good yields of nitroarenes, nitroso derivatives were formed when the reaction was performed at room temperature [38].

The oxidation of aryl amines was also performed under homogeneous conditions in the presence of a lacunary Keggin-type heteropolyanion having mixed tungsten and molybdenum addenda atoms [39]. The catalyst, easily prepared from $\mathrm{K}_{7}\left[\mathrm{PMo}_{2} \mathrm{~W}_{9} \mathrm{O}_{39}\right] \cdot 19 \mathrm{H}_{2} \mathrm{O}$ upon replacement of $\mathrm{K}^{+}$with tetrabutylamonium ion, was employed to prepare methyl-, chloro-, and methoxy-substituted nitrobenzenes from the corresponding anilines, using $\mathrm{H}_{2} \mathrm{O}_{2}$ as the oxidant (Scheme 12).

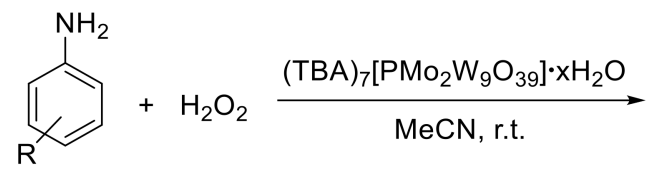<smiles>[R]c1ccc([N+](=O)[O-])cc1</smiles>

$1,91-95 \%$

$\mathrm{R}=$ 2-Me, 4-Me, 2-Cl, 4-Cl, 2-MeO

Scheme 12. Oxidation of anilines to nitroarenes with hydrogen peroxide catalysed by $\alpha-\left[\mathrm{PMo}_{2} \mathrm{~W}_{9} \mathrm{O}_{39}\right]^{7-}$. a Range of conversion is reported.

Tundo, Aricò, et al. reported a heteropolyacid-catalysed oxidation of anilines to the nitroarenes with hydrogen peroxide in a multiphasic system, which comprises isooctane, Aliquat 336, and water. The nature of the heteropolyacid catalyst and the reaction temperature proved to be crucial for the selectivity of the oxidation process. Nitroarenes were selectively formed upon using $\mathrm{HFePMo}{ }_{11} \mathrm{VO}_{40}$ as the catalyst at $60^{\circ} \mathrm{C}$; on the other hand, performing the reaction at $20^{\circ} \mathrm{C}$ provided good yields of nitrosoarenes [40]. 
Newmann et al. also reported the use of a water-soluble "sandwich" type polyoxometalate catalyst, $\mathrm{Na}_{12}\left[\mathrm{WZn}_{3}\left(\mathrm{H}_{2} \mathrm{O}\right)_{2}\right]\left[\left(\mathrm{ZnW}_{9} \mathrm{O}_{34}\right)_{2}\right]$, for the oxidation of organic compounds with hydrogen peroxide. Similarly to the above-described perfluoroketone-silicatecatalysed procedure, anilines were converted into the corresponding azoxy or nitro derivatives depending on the nature of substituents at the aromatic ring. Indeed, while hydroxyand alkoxy-substituted electron-rich anilines as well as nitro-substituted electron-poor anilines gave nitroarenes, although with reduced conversion values, alkyl- and halo-substituted anilines efficiently yielded azoxyarenes. On the other hand, pyridine derivatives-especially electron-rich substrates-were converted into the corresponding $N$-oxides. Notably, the catalyst could be recovered by simple phase separation and reused in further oxidative cycles without significant loss in activity or selectivity [41].

The $\mathrm{MoO}_{3} / \mathrm{KOH}$-catalysed oxidation of arylamines with hydrogen peroxide provides an efficient route to the corresponding nitroso-arenes. However, nitroarenes were obtained when $\left(\mathrm{NH}_{4}\right)_{6} \mathrm{Mo}_{7} \mathrm{O}_{24} \cdot 4 \mathrm{H}_{2} \mathrm{O}$ was used as the catalyst with 6.0 eq of $\mathrm{H}_{2} \mathrm{O}_{2}$. This protocol was applied to the synthesis of nitrobenzene, 1-chloro-4-nitrobenzene, and 1,4-dinitrobenzene with $66 \%, 92 \%$, and $68 \%$ yields respectively [42].

Besides the above-described procedures, a number of transition-metal-free practical and efficient routes for the transformation of anilines to nitroarenes have recently emerged.

Voutyritsa et al. reported that anilines react with hydrogen peroxide in a mixture of acetonitrile and an aqueous buffer solution $\left(0.6 \mathrm{M} \mathrm{K}_{2} \mathrm{CO}_{3}, 4 \times 10^{-4} \mathrm{M}\right.$ EDTA disodium salt, $\mathrm{pH}$ 11) providing the corresponding nitroarenes with good-to-high yield. The reaction is amenable to the oxidation of substrates bearing electron-withdrawing and electrondonating moieties at different positions of the aromatic ring (Scheme 13) [43].

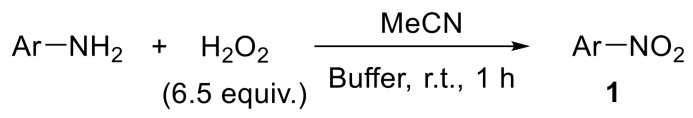

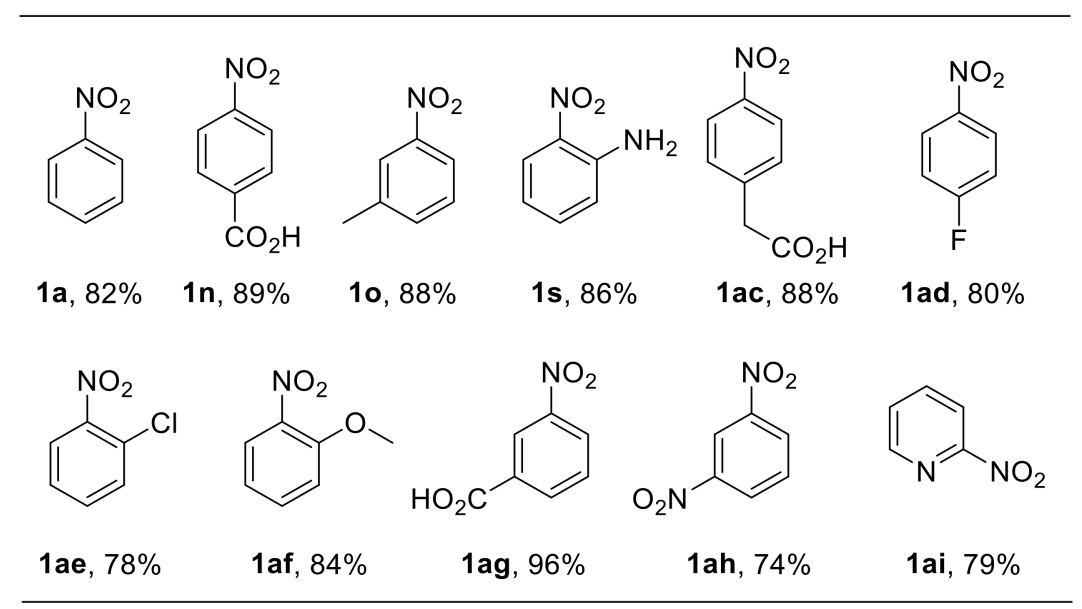

Scheme 13. Oxidation of aryl amines to nitroarenes with $\mathrm{H}_{2} \mathrm{O}_{2}$ in acetonitrile/buffer $\left(0.6 \mathrm{M} \mathrm{K}_{2} \mathrm{CO}_{3}\right.$, $4 \times 10^{-4} \mathrm{M}$ EDTA disodium salt, $\mathrm{pH}$ 11) (selected examples from Voutyritsa et al.).

High resolution mass spectroscopy (HRMS)-based mechanistic studies provided insights into the nature of the intermediates involved. The reaction mechanism reasonably proceeds through the formation of benzimidine $\mathbf{1 0}$ from aniline and acetonitrile with hydrogen peroxide under the reaction conditions; the benzimidine $\mathbf{1 0}$ is then oxidised to oxaziridine 11 (Scheme 14). Nitrosobenzene 3 can be formed via two different paths involving i) the reaction of the aniline with oxaziridine 11, which behaves as the oxidant and ii) the ring expansion of $\mathbf{1 1}$ to the four-membered heterocyclic derivative $\mathbf{1 2}$, followed by a retro [2 +2$]$ cycloaddition to give the nitrosoarene 3 . This latter pathway (alternative path in Scheme 14) is more likely to occur as no literature precedents report the oxidation of anilines to nitrosobenzene with oxaziridines. The final oxidation step converts the nitrosoarene 3 into the corresponding nitro derivative $\mathbf{1}$ [43]. Notably, when anilines 
were treated with hydrogen peroxide under similar reaction conditions but using a catalytic amount of 2,2,2-trifluoroacetophenone, azoxyarenes were selectively formed with good yield.

Proposed reaction mechanism

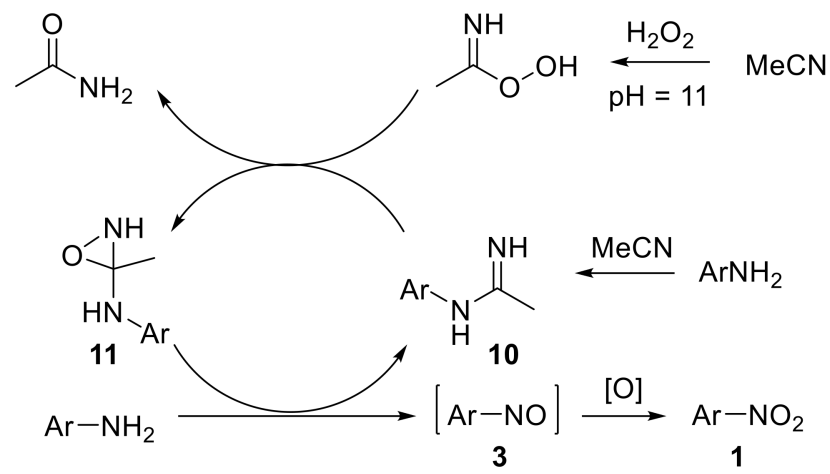

Alternative path

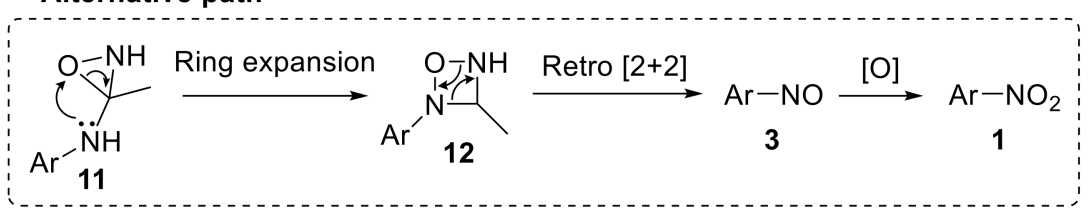

Scheme 14. Proposed reaction mechanism for the oxidation of aryl amines to nitroarenes with $\mathrm{H}_{2} \mathrm{O}_{2}$ in acetonitrile/buffer $\left(0.6 \mathrm{M} \mathrm{K}_{2} \mathrm{CO}_{3}, 4 \times 10^{-4} \mathrm{M}\right.$ EDTA disodium salt, $\left.\mathrm{pH} 11\right)$.

Sashidhara et al. recently described a base-promoted approach for the oxidative conversion of aryl amines to nitroarenes using hydrogen peroxide. The reaction quickly occurs at ambient temperature using acetonitrile as the solvent and $\mathrm{K}_{2} \mathrm{CO}_{3}$ as the base promoter [44]. Remarkably, the reaction scope proved to be broad, encompassing differently substituted substrates. Generally, electron-rich aryl amines gave the corresponding nitroarenes at higher yields compared with electron-poor anilines. The reaction was also extended to the oxidation of heteroaromatic amines (Scheme 15).

$$
\mathrm{Ar}-\mathrm{NH}_{2} \underset{\mathrm{MeCN} \text {, r.t., } 10 \mathrm{~min}}{\stackrel{\mathrm{K}_{2} \mathrm{CO}_{3} \text { (1.0 eq.) }}{\longrightarrow}} \quad \begin{gathered}
\mathbf{A r}-\mathrm{NO}_{2} \\
\mathbf{1}
\end{gathered}
$$

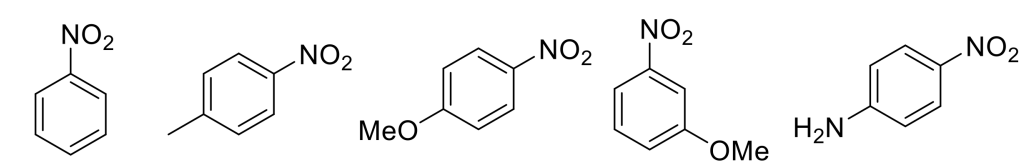

1a, $94 \%$

1b, $90 \%$

$1 d, 92 \%$

$1 p, 80 \%$

$1 \mathrm{aj}, 80 \%$<smiles>CC(=O)c1ccc([N+](=O)[O-])cc1</smiles><smiles>O=[N+]([O-])c1ccccc1I</smiles><smiles>Cc1ccc([N+](=O)[O-])cc1F</smiles><smiles>Cc1cc([N+](=O)[O-])n(-c2ccccc2)n1</smiles>

1ak, $85 \%$

1al, $85 \%$

1am, 65\%

1an, $72 \%$

1ao, $70 \%$

Scheme 15. Selected examples from Sashidhara et al. of base-promoted oxidation of anilines with hydrogen peroxide.

A polymer of a silane functionalised with octafluoroacetophenone was also used as a heterogeneous catalyst for the oxidation of alkenes and aromatic amines with hydrogen peroxide [45]. While pyridine derivatives were converted into the corresponding 
oxides, anilines gave azoxyarenes or nitroarenes, depending on the nature of the substituents onto the aromatic ring. Particularly, aniline and alkyl- and halo-substituted anilines provided dimeric azoxy derivatives with quantitative yields. On the other hand, when this perfluoroketone-silicate-catalysed approach was applied to electron-rich hydroxysubstituted anilines and electron-poor 3-nitroaniline, the corresponding nitroarenes were selectively obtained. Additionally, substrates bearing the nitro substituent ortho to the amino group proved to be unreactive, probably because of the presence of intramolecular hydrogen bonding between the amino and the nitro substituent [45].

Chalcogen-containing compounds have also been used as catalysts or promoters to accomplish a number of oxidative functional-group interconversions. In particular, a wide range of organoselenium-promoted oxidation methodologies have emerged as versatile synthetic transformations [46-50]. For example, selenium-catalysed routes for the oxidation of organic compounds including, among others, alkenes [50-52], alcohols [50,53], alkynes [50], and carbonyl derivatives [50] have been developed. Additionally, biologically relevant selenium-catalysed thiol-disulfide interconversions have been widely investigated over the past few years [54-61].

In this context, the selenium-catalysed oxidation of anilines has also been studied, enabling the development of selective procedures for the synthesis of nitroarenes [62], nitrosoarenes [63], and azoxyarenes [62,64]. Indeed, a broad array of differently substituted anilines were smoothly converted into the corresponding nitroarenes $\mathbf{1}$ upon reaction with hydrogen peroxide in the presence of diphenyl diselenide or benzeneseleninic acid (Scheme 16); the methodology encompasses both electron-rich and electron-poor substrates and can be efficiently applied to the synthesis of nitroarenes at a gram scale [62]. Amongst a variety of organoselenides investigated, diphenyl diselenide and benzeneseleninic acid gave better results in terms of yield and selectivity. On the other hand, the reaction of aniline with hydrogen peroxide in the presence of selenium dioxide $\left(\mathrm{SeO}_{2}\right)$ or sodium selenite $\left(\mathrm{Na}_{2} \mathrm{SeO}_{3}\right)$ provided a good yield of the corresponding azoxyarenes.

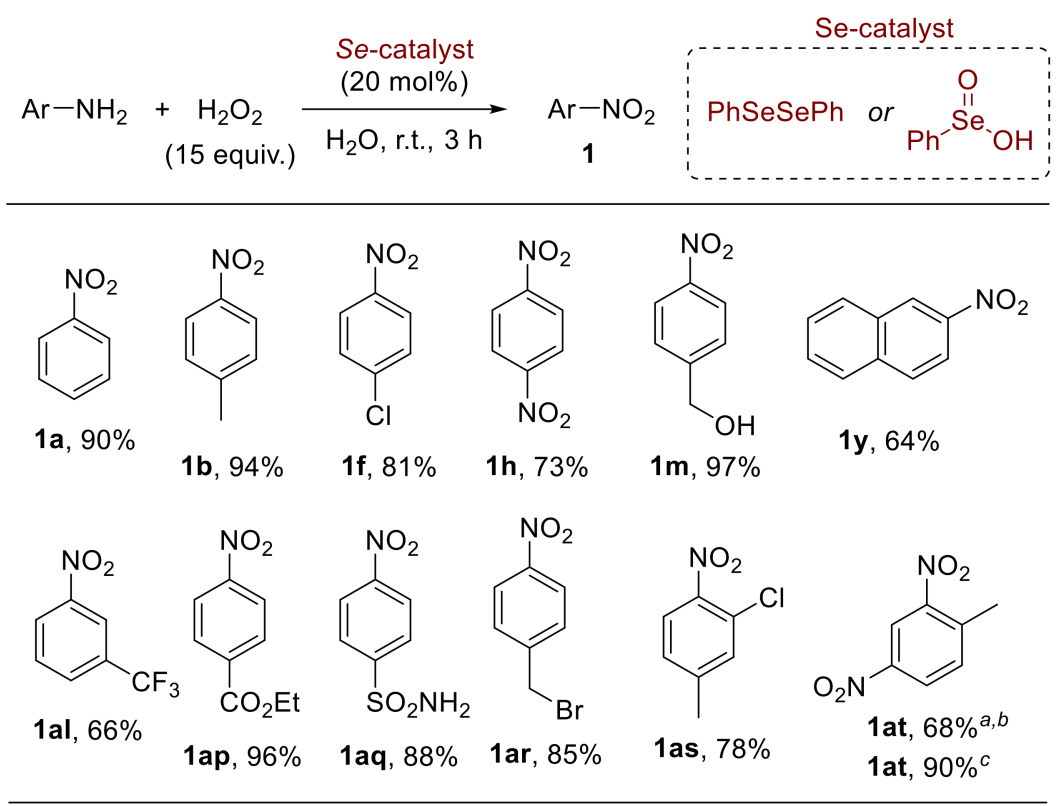

Scheme 16. Organoselenium-mediated oxidation of anilines to nitroarenes. Similar results were achieved by using diphenyl diselenide or benzeneseleninic acid (selected examples). ${ }^{\text {a }}$ The reaction was performed at $60^{\circ} \mathrm{C}^{\text {; }}$ Obtained from 2-methyl-5-nitroaniline; ${ }^{\mathrm{c}}$ Obtained from 4-methyl-3-nitroaniline.

Control experiments and ${ }^{77} \mathrm{Se}-\mathrm{NMR}$-based studies suggested that the reaction mechanism probably proceeds through Se (IV) species. The proposed mechanism is reported in Scheme 17. Diphenyl diselenide behaves as a precatalyst, and the first steps of the reaction mechanism involve its sequential oxidation to benzeneselenenic acid $\mathbf{1 3}$ and, finally, 
to benzeneseleninic acid 14. The latter is the active catalytic species involved in the oxidation of anilines. The reaction of $\mathbf{1 4}$ with hydrogen peroxide in water is expected to provide the peroxyselenurane 15, which can be dehydrated to afford peroxyseleninic acid $\mathbf{1 6}$ or selenonic acid 17. The reaction of selenonic acid $\mathbf{1 7}$ with seleninic acid $\mathbf{1 4}$ might also provide the selenonium salt $\mathbf{1 8}$, which, in aqueous solution, is readily reconverted into the parent acids 14 and 17. Both 15 and 16 are believed to behave as active oxidants. The reaction of aniline with 15 or 16 yields the hydroxylamine 19, which is further oxidised to dihydroxylamine 20. Benzeneseleninic acid is regenerated in both these steps. A benzeneseleninic-acid-mediated dehydration of $\mathbf{2 0}$ provides nitrosoarene. Finally, the reaction of nitrosoarene 3 with $\mathbf{1 6}$ provides nitroarene $\mathbf{1}$ and regenerates benzeneseleninic acid 14 [62]. Notably, while other selenium-mediated oxidation reactions of organic compounds (i.e., epoxidation of olefins) involve key Se (VI) species [65], the on water oxidation of anilines to nitroarenes proceeds through Se (IV) key oxidant species.

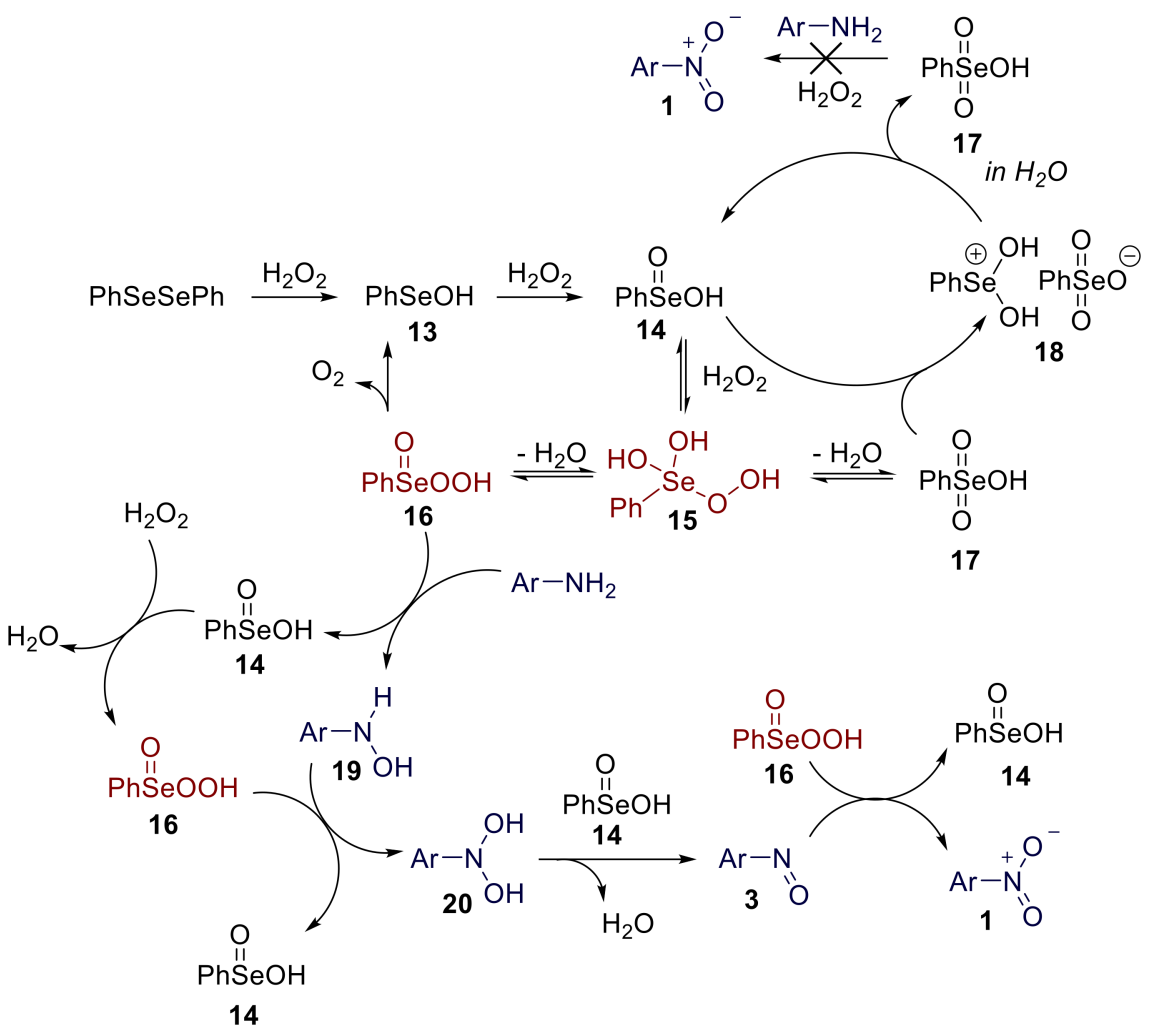

Scheme 17. Proposed mechanism for the organoselenium-promoted oxidation of anilines to nitroarenes.

Marinescu et al. reported the synthesis of new $\alpha$ - and $\beta$-cyclodextrin derivatives with good enzyme-like activity in the oxidation of alcohols with $\mathrm{H}_{2} \mathrm{O}_{2}$ [66]. In this context, different cyclodextrin derivatives (Figure 2, left) have also been described to catalyse the oxidation of anilines to nitroarenes [67]. The mechanism proposed for the oxidation of anilines under cyclodextrins-catalysed conditions involves the reaction of hydrogen peroxide with the ketone moiety of the catalyst to form the peroxide adduct, which is the active oxidant species. The aniline, bound in the cavity of cyclodextrin (Figure 2, right), is oxidised to the corresponding hydroxylamine, which is subsequently converted to the nitroso derivative and then to the nitroarene [67]. 

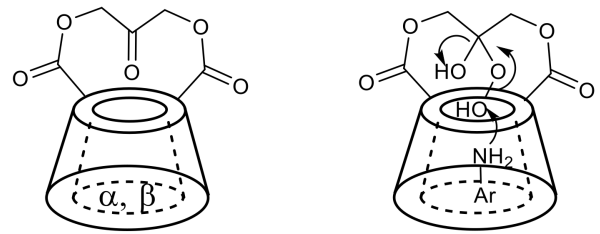

Figure 2. Cyclodextrin ketone catalysts (left); proposed mechanism for the catalysis (right).

\section{Oxidation with Sodium Perborate}

Sodium perborate $\left(\mathrm{NaBO}_{3} \cdot 4 \mathrm{H}_{2} \mathrm{O}\right.$, SPB) has also been employed as an efficient oxidant for the conversion of anilines to nitroarenes. McKillop and Tarbin reported that anilines bearing electron-withdrawing groups are smoothly oxidised to the corresponding nitro derivatives upon reaction with sodium perborate in acetic acid at $50-55^{\circ} \mathrm{C}$. Electron-rich anilines provided lower yields of nitroarenes because of the formation of over-oxidised side products [68].

In this context, Firouzabadi et al. developed a convenient tungstophosphoric acid $\left(\mathrm{H}_{3} \mathrm{PW} \cdot n \mathrm{H}_{2} \mathrm{O}\right)$-catalysed approach for the oxidation of anilines with sodium perborate in aqueous basic media. Cetyltrimethylammonium bromide (CTAB) was used as the micelle source [69]. Notably, this methodology proved to be particularly effective with electron-rich anilines, leading to the corresponding nitroarenes with good yield. On the other hand, substrates bearing electron-withdrawing substituents provided nitroarenes at lower yield (Scheme 18) [69].

$$
\begin{array}{ccc} 
& \mathrm{H}_{3} \mathrm{PW} \cdot n \mathrm{H}_{2} \mathrm{O}(1 \mathrm{~mol} \%) \\
\mathrm{Ar}-\mathrm{NH}_{2}+\mathrm{SPB} \text { (7.0 eq.) } & \mathrm{CTAB} & \mathrm{Ar}-\mathrm{NO}_{2} \\
{^{\circ} \mathrm{C}, 12 \mathrm{~h}} } & \mathbf{1}
\end{array}
$$

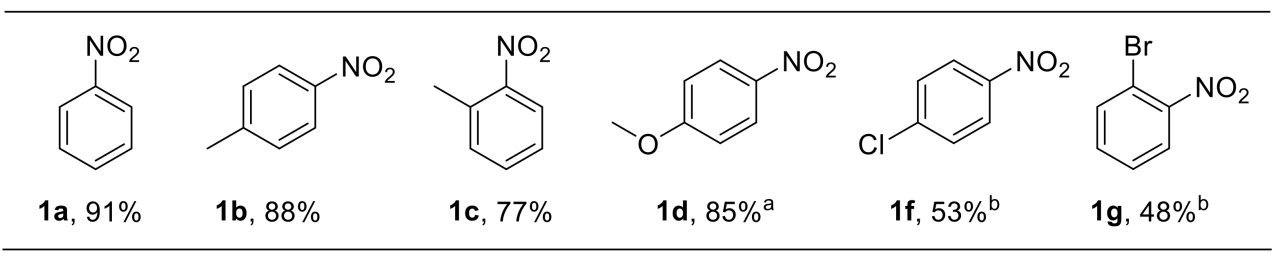

Scheme 18. Tungstophosphoric-acid-catalysed oxidative conversion of anilines to nitroarenes (selected examples). ${ }^{a}$ Reaction time: $10 \mathrm{~h} ;{ }^{\mathrm{b}} 10 \mathrm{~mol} \%$ of tungstophosphoric acid was used.

Habibi et al. reported the oxidative conversion of electron-rich anilines into the corresponding nitroarenes in micellar media using sodium perborate $\left(\mathrm{NaBO}_{3} \cdot 4 \mathrm{H}_{2} \mathrm{O}\right)$ in the presence of catalytic amounts of silica sulfuric acid (SSA). Cetyltrimethylammonium bromide (CTAB) was used as a phase transfer catalyst in the optimised protocol (Scheme 19). The use of a cheap, safe, and easy to handle reagent such as SSA represents an advantage of this procedure which, however, is limited to anilines bearing electron-donating groups and cannot be extended to electron-poor substrates [70].

$$
\mathrm{Ar}-\mathrm{NH}_{2} \underset{60^{\circ} \mathrm{C}, 12 \mathrm{~h}}{\stackrel{\mathrm{SSA}, \mathrm{SPB}, \mathrm{CTAB}}{\longrightarrow}} \mathrm{Ar}-\mathrm{NO}_{2}
$$

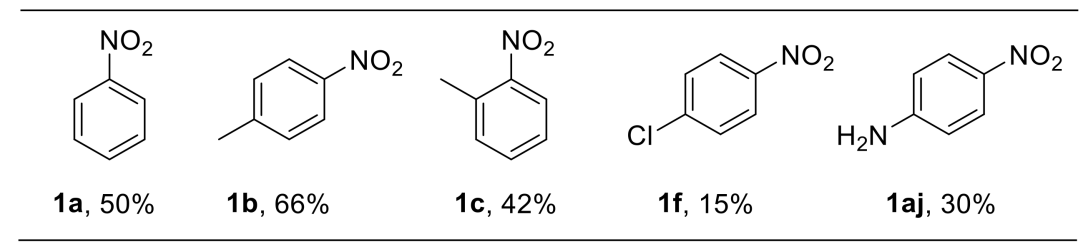

Scheme 19. Silica-sulfuric-acid-catalysed oxidation of arylamines to nitroarenes with sodium perborate (selected examples). SSA: silica sulfuric acid; SPB: sodium perborate $\left(\mathrm{NaBO}_{3} \cdot 4 \mathrm{H}_{2} \mathrm{O}\right) ; \mathrm{CTAB}$ : cetyltrimethylammonium bromide. 


\section{Oxidation with Dimethyldioxirane}

In 1986, Murray et al. described a rapid and efficient synthesis of nitro compounds through the oxidation of the corresponding anilines with dimethyldioxirane [71,72]. Solutions of dimethyldioxirane in acetone can be easily prepared using Oxone ${ }^{\circledR}$ as the oxidant [73]. Notably, this procedure could be applied both to aromatic and aliphatic amines, providing nitroarenes 1 and nitroalkanes 4 with high yield (Scheme 20). Zabrowski et al. also reported the oxidation of electron-rich anilines to nitroarenes upon using dimethyl dioxirane generated in situ from acetone and Oxone ${ }^{\circledR}$ under phase-transfer conditions [74].

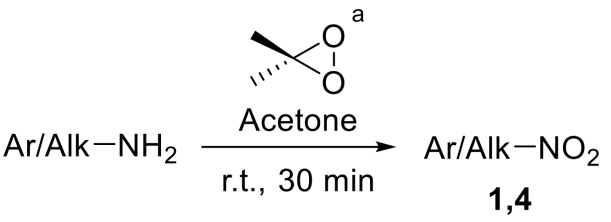<smiles>O=[N+]([O-])c1ccccc1</smiles>

1a, $97 \%$<smiles>COc1ccc([N+](=O)[O-])cc1</smiles>

1d, $94 \%$<smiles>NC1CCCCC1</smiles>

$4 a, 95 \%$<smiles>CCCCN</smiles>

4b, $84 \%$<smiles>CCC(C)[N+](=O)[O-]</smiles>

$4 c, 87 \%$<smiles>O=[N+]([O-])C12CC3CC(CC(C3)C1)C2</smiles>

4d, $95 \%$

Scheme 20. Synthesis of nitro derivatives via oxidation of amines with dimethyldioxirane. ${ }^{\text {a Dimethyl- }}$ dioxirane solution was generated in situ from acetone and Oxone ${ }^{\circledR}$.

The oxidation of anilines to nitroarenes was also performed using Oxone ${ }^{\circledR}$ in $5-20 \%$ aqueous acetone buffered with an excess of sodium bicarbonate. Lower yields were achieved when the reaction was conducted in the absence of acetone, thus suggesting a plausible formation of dimethyldioxirane as a competing oxidant in the presence of acetone [75].

In this context, polystyrene-supported dioxirane has also been reported as a versatile, recyclable oxidising reagent to convert anilines into nitroarenes [76]. Some of the drawbacks related to the use of dimethyl dioxirane-such as its instability with respect to heat and light - can be overcome by incorporating the reagent function into a crosslinked styrene-divinylbenzene copolymer matrix. Such a polystyrene-supported dioxirane resin 21, prepared in six steps from styrene-divinylbenzene copolymer beads (Scheme 21a), proved to act as an efficient oxidant for the conversion of anilines into the corresponding nitroarenes (Scheme 21b). Notably, the dioxirane resin also enabled the oxidation of pyridine and lutidine into their $\mathrm{N}$-oxides [76].

The use of a $\mathrm{MnSO}_{4} / \mathrm{Oxone}{ }^{\circledR} / \mathrm{H}_{2} \mathrm{O}$ system for the oxidation of organic compounds has been described. Manganese species, behaving as Lewis acids, facilitate the cleavage of oxygen-oxygen bonds during oxidation reactions. Such an oxidant also enabled the rapid and efficient conversion of anilines to nitroarenes (Scheme 22). Electron-rich substrates underwent oxidation in shorter times and with higher yields compared to electron-poor ones [77]. 
a) Synthesis of polystyrene-supported dioxirane resin $\mathbf{2 1}$

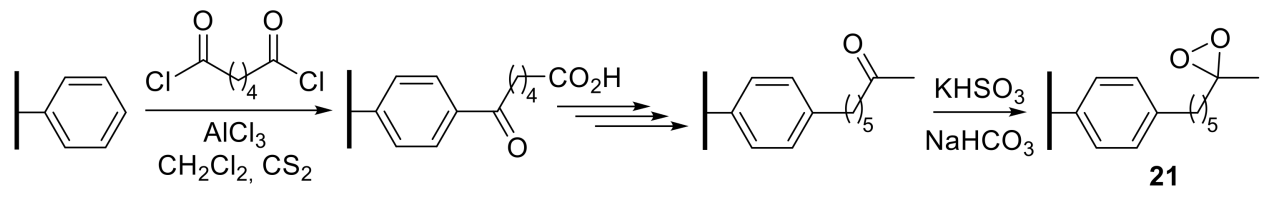

b) Use of the polystyrene-supported dioxirane resin $\mathbf{2 1}$ in the oxidation of anilines

$$
\mathrm{Ar}-\mathrm{NH}_{2} \underset{\text { r.t., } 32-53 \mathrm{~h}}{\stackrel{21, \mathrm{CHCl}_{3}}{\longrightarrow}} \mathrm{Ar}-\mathrm{NO}_{2}
$$

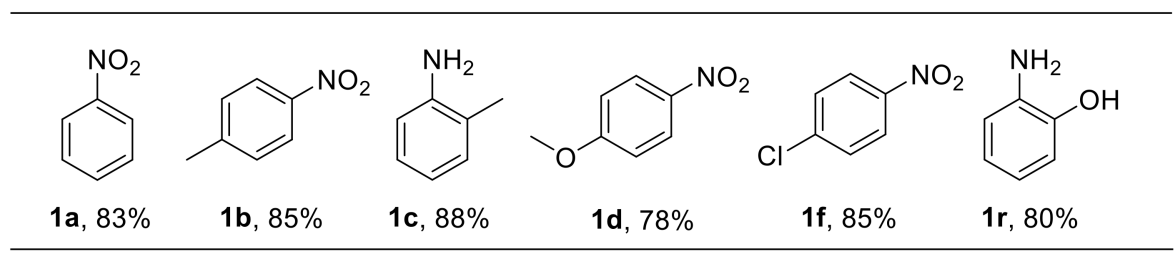

Scheme 21. Synthesis of polystyrene-supported dioxirane (a) and its use in the oxidation of anilines to nitroarenes (b).

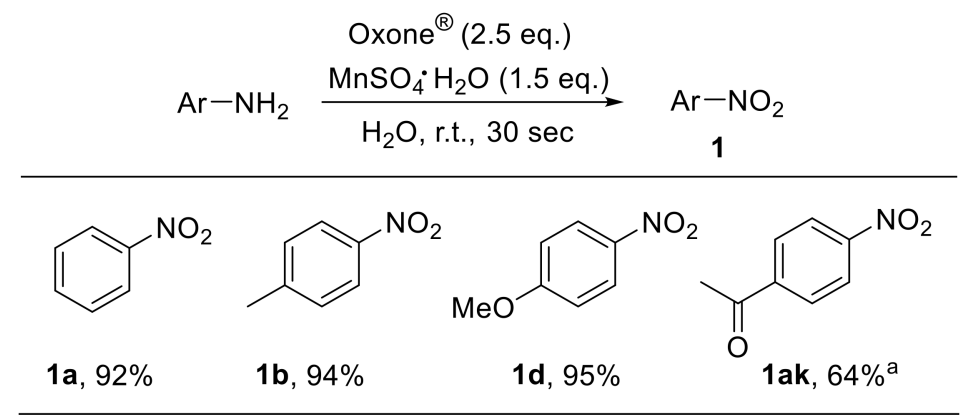

Scheme 22. Oxidation of anilines under manganese sulfate/Oxone ${ }^{\circledR} /$ water conditions. ${ }^{\text {a }}$ Reaction time: $1 \mathrm{~h}$.

\section{Oxidations with Other Oxidising Agents}

The HOF.MeCN complex is an effective oxygen transfer agent which has been employed in a wide variety of oxidative transformations, including oxidation of amines to nitro derivatives [78-80]. The by-product arising from reactions involving $\mathrm{HOF} \cdot \mathrm{MeCN}$ is $\mathrm{HF}$, which, in principle, may be recovered and converted to fluorine by electrolysis. For this reason, such a complex is considered to have a low environmental impact. The relatively poor stability of the HOF.MeCN complex (half-life at room temperature of approximately $4 \mathrm{~h}$ ) and the undesired transformations often occurring in highly concentrated oxidising media represent the main drawbacks of $\mathrm{HOF} \cdot \mathrm{MeCN}-$ based procedures. McPake et al. aimed to address these issues by developing a sequential continuous flow process for the oxidation of amines [81]. Fluorine and aqueous acetonitrile are reacted to generate HOF.MeCN, which is immediately treated with the amine in a single, sequential, twostep flow process. The methodology could be successfully applied to the oxidation of aliphatic and aromatic substrates providing high yields of the corresponding nitroalkanes and nitroarenes (Scheme 23). A related procedure was also employed for the oxidation of azides. 


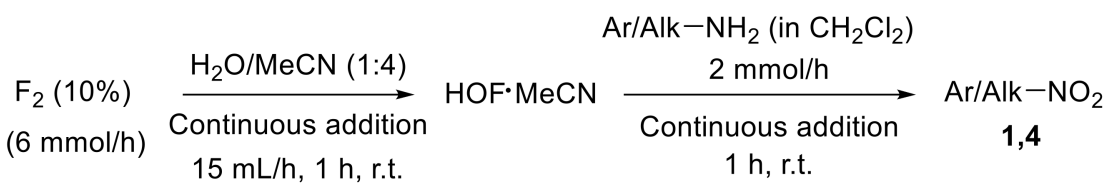<smiles>O=[N+]([O-])c1ccc(F)cc1F</smiles>

1a, $61 \%$ 1au, $69 \%$<smiles>O=[N+]([O-])c1c(F)nc(F)c(F)c1S(=O)(=O)c1ccccc1</smiles>
1av, 95\%<smiles>O=[N+]([O-])C1CCCCC1</smiles>

4a, $95 \%$<smiles>O=[N+]([O-])C1CCCCC1</smiles>

$4 \mathbf{e}, \mathrm{n}=5,80 \%$
$\mathbf{4 f}, \mathrm{n}=11,95 \%$<smiles>O=[N+]([O-])C1CCCCC1[N+](=O)[O-]</smiles>

4g, $95 \%$

Scheme 23. Continuous flow process for the oxidation of amines with HOF-MeCN. Selected examples.

The oxidation of aniline with bis(bipyridine)silver(II) peroxydisulfate $\left\{\left[\mathrm{Ag}(\text { bipy })_{2}\right] \mathrm{S}_{2} \mathrm{O}_{8}\right\}$ has also been described (Scheme 24) [82,83]. However, the formation of an unidentified by-product along with nitrobenzene 1a was observed [82].

$$
\begin{array}{cc}
\multicolumn{2}{c}{\mathrm{Ag}(\text { bipy })_{2} \mathrm{~S}_{2} \mathrm{O}_{8}} \\
\mathrm{PhNH}_{2} \stackrel{\text { wet } \mathrm{MeCN}}{\stackrel{30 \text { min, r.t. }}{\longrightarrow}} \mathrm{PhNO}_{2} \mathbf{1 a}, 80 \%
\end{array}
$$

Scheme 24. Oxidation of aniline to nitrobenzene using $\left[\mathrm{Ag}(\text { bipy })_{2}\right] \mathrm{S}_{2} \mathrm{O}_{8}$.

Das et al. reported the use of tetra- $n$-alkylammonium bromates as efficient and easy-tohandle oxidising agents for the conversion of arylamines into the corresponding nitroarenes (Scheme 25) [84].

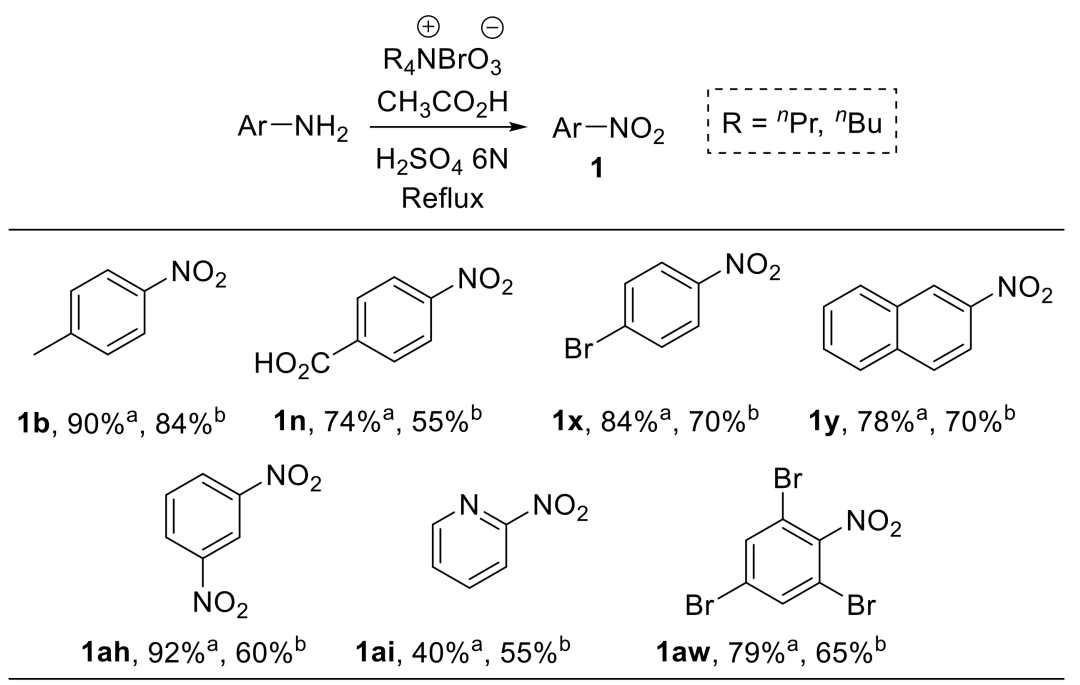

Scheme 25. Oxidation of aromatic amines to nitroarenes using $n$-alkylammonium bromates (selected examples). ${ }^{\mathrm{a}} \mathrm{R}=n$-propyl; ${ }^{\mathrm{b}} \mathrm{R}=n$-butyl. The refluxing time was generally between 1 and $10 \mathrm{~h}$, depending on the nature of both the substrate and the alkyl bromate.

Tetra- $n$-alkylammonium bromates were obtained upon treatment of the corresponding bromides with chlorine gas in an alkaline medium. The reaction showed a broad substrate scope; differently substituted nitrobenzenes, as well as 2-nitronaphthalene 1y and 2-nitropyridine 1a,i, were efficiently prepared by selective oxidation of the parent amine under the conditions reported in Scheme 25.

\section{Conclusions and Perspectives}

Nitro compounds are an important and versatile class of organic compounds. Owing to their applications, ranging from organic synthesis and materials science to medicinal 
chemistry and drug science, the development of practical and efficient methods for the synthesis of nitro compounds has attracted considerable interest. A wide variety of synthetic approaches have thus emerged over the past decades. In this context, the oxidation of amines is an alternative and valuable route towards nitro derivatives.

Oxidation-based methodologies do not suffer from regioselectivity issues; this represents their main advantage over some nitration strategies. On the other hand, significant historical drawbacks of oxidation-based approaches are related to the formation of mixtures of oxidised products (i.e.,- - for the oxidation of aryl amines-nitroarenes, azoxyarenes, nitrosoarenes) and to the poor compatibility with respect to labile functional groups. A number of protocols for the oxidation of amines to nitro compounds have been developed, and considerable efforts have been devoted to addressing the above-mentioned limitations.

Focusing on nitroarenes, this review summarises the progress in their synthesis via oxidation of aryl amines. Efficient and convenient methods for the preparation of differently functionalised nitroarenes have been reported. The different reaction conditions, as well as the use of different catalysts and oxidising agents, enabled high selectivity and a rather broad functional-group tolerance to be achieved. A synthetic overview of some of the discussed methodologies, focusing on the catalyst, the oxidant, the scope, and limitations is reported in Table 1. Promoters, used in stoichiometric or superstoichiometric amounts, are reported in the second column.

Table 1. Synthetic overview of methodologies for the oxidative conversion of amines to nitro compounds.

\begin{tabular}{|c|c|c|c|c|c|}
\hline Entry & Catalyst/Promoter & Conditions & Scope (Substrates) & Limitations & Ref. \\
\hline 1 & none & $\begin{array}{l}\text { Peracetic acid; refluxing } \\
\mathrm{CHCl}_{3} \text { or } \mathrm{CH}_{2} \mathrm{Cl}_{2}\end{array}$ & Mainly $\mathrm{ArNH}_{2}$ & $\begin{array}{l}\text { Formation of variable amounts of } \\
\text { azoxyarenes }\end{array}$ & [19] \\
\hline 2 & none & $\begin{array}{l}m \text {-CPBA; refluxing } \\
\mathrm{Cl}\left(\mathrm{CH}_{2}\right)_{2} \mathrm{Cl}\end{array}$ & $\begin{array}{l}\text { Electron-rich and } \\
\text { electron-poor } \mathrm{ArNH}_{2}\end{array}$ & - & [25] \\
\hline 3 & none & $\begin{array}{l}\text { Nonanebis (peroxoic } \\
\text { acid); } \mathrm{MeCN}, 50{ }^{\circ} \mathrm{C}\end{array}$ & $\begin{array}{l}\text { Electron-rich and } \\
\text { electron-poor } \mathrm{ArNH}_{2}\end{array}$ & $\begin{array}{l}\text { Driven by the nature of the group } \\
\text { at the ortho position. This also } \\
\text { enabled regioselective oxidations } \\
\text { for diamines. }\end{array}$ & [29] \\
\hline 4 & CuAlPO-5 & $\mathrm{TBHP}, \mathrm{MeCN}, 60^{\circ} \mathrm{C}$ & $\begin{array}{l}\text { Electron-rich and } \\
\text { electron-poor } \mathrm{ArNH}_{2}\end{array}$ & $\begin{array}{c}\text { Moderate selectivity for some } \\
\text { substrates }\end{array}$ & {$[30]$} \\
\hline 5 & $\mathrm{CrS}-2$ & TBHP; refluxing $\mathrm{MeOH}$ & $\mathrm{ArNH}_{2}$ and $\mathrm{AlkNH}$ & - & {$[31]$} \\
\hline 6 & $\mathrm{Rh}_{2}(\mathrm{cap})_{4}$ & $\begin{array}{l}\mathrm{TBHP} ; \mathrm{CH}_{2} \mathrm{Cl}_{2} \\
\quad \mathrm{NaHCO}_{3}\end{array}$ & $\begin{array}{l}\text { Mainly electron-rich } \\
\mathrm{ArNH}_{2}\end{array}$ & $\begin{array}{c}\text { Low yields for electron-poor } \\
\text { ArNH }_{2} \text { and for } o \text {-aryl-substituted } \\
\text { anilines }\end{array}$ & [32] \\
\hline 7 & Ti catalyst & $\mathrm{H}_{2} \mathrm{O}_{2} ; \mathrm{MeOH}$, r.t. & $\begin{array}{l}\text { Electron-rich and } \\
\text { electron-poor } \mathrm{ArNH}_{2} \text {. } \\
\mathrm{AlkNH}_{2} \text { gave oximes. }\end{array}$ & $\begin{array}{l}\text { Formation of variable amounts of } \\
\text { azoxyarenes and nitrosoarenes }\end{array}$ & [36] \\
\hline 8 & $\begin{array}{l}\text { Buffer }\left(\mathrm{K}_{2} \mathrm{CO}_{3}\right. \\
\text { EDTA disodium })\end{array}$ & $\mathrm{H}_{2} \mathrm{O}_{2} ; \mathrm{MeCN}$, r.t. & $\begin{array}{l}\text { Electron-rich and } \\
\text { electron-poor } \mathrm{ArNH}_{2} \text {. }\end{array}$ & - & [43] \\
\hline 9 & $\mathrm{~K}_{2} \mathrm{CO}_{3}$ & $\mathrm{H}_{2} \mathrm{O}_{2} ; \mathrm{MeCN}$, r.t. & $\begin{array}{l}\text { Electron-rich and } \\
\text { electron-poor } \mathrm{ArNH}_{2} \text {. }\end{array}$ & - & {$[44]$} \\
\hline 10 & $\begin{array}{l}\text { PhSeSePh or } \\
\mathrm{PhSe}(\mathrm{O}) \mathrm{OH}\end{array}$ & $\mathrm{H}_{2} \mathrm{O}_{2} ; \mathrm{H} 2 \mathrm{O}$, r.t. & $\begin{array}{l}\text { Electron-rich and } \\
\text { electron-poor } \mathrm{ArNH}_{2} \text {. }\end{array}$ & $\begin{array}{l}\text { Variable amount of azoxyarenes } \\
\text { for some substrates }\end{array}$ & {$[62]$} \\
\hline 11 & $\mathrm{H}_{3} \mathrm{PW} \cdot n \mathrm{H}_{2} \mathrm{O}$ & $\mathrm{SPB} ; \mathrm{CTAB}, 55-60^{\circ} \mathrm{C}$ & $\begin{array}{l}\text { Mainly electron-rich } \\
\mathrm{ArNH}_{2}\end{array}$ & $\begin{array}{l}\text { Low yields for electron-poor } \\
\qquad \mathrm{ArNH}_{2}\end{array}$ & [69] \\
\hline 12 & SSA & $\mathrm{SPB} ; \mathrm{CTAB}, 60^{\circ} \mathrm{C}$ & Electron-rich $\mathrm{ArNH}_{2}$ & $\begin{array}{l}\text { Low yields for electron-poor } \\
\qquad \mathrm{ArNH}_{2}\end{array}$ & {$[70]$} \\
\hline 13 & none & $\begin{array}{l}\text { Dimethyldioxirane } \\
\text { (from Oxone }{ }^{\circledR} \text { and } \\
\text { acetone), r.t. }\end{array}$ & $\mathrm{ArNH}_{2}$ and $\mathrm{AlkNH}_{2}$ & - & {$[73,74]$} \\
\hline 14 & none & $\begin{array}{l}\text { Polystyrene-supported } \\
\text { dioxirane; } \mathrm{CH}_{2} \mathrm{Cl}_{2} \text {, r.t. }\end{array}$ & $\begin{array}{l}\text { Electron-rich and } \\
\text { electron-poor } \mathrm{ArNH}_{2}\end{array}$ & - & [76] \\
\hline 15 & $\mathrm{MnSO}_{4}$ & Oxone $^{\circledR} ; \cdot \mathrm{H}_{2} \mathrm{O}$, r.t. & $\begin{array}{l}\text { Mainly electron-rich } \\
\mathrm{ArNH}_{2}\end{array}$ & $\begin{array}{l}\text { Lower yields for electron-poor } \\
\qquad \mathrm{ArNH}_{2}\end{array}$ & {$[77]$} \\
\hline
\end{tabular}


Table 1. Cont.

\begin{tabular}{|c|c|c|c|c|c|}
\hline Entry & Catalyst/Promoter & Conditions & Scope (Substrates) & Limitations & Ref. \\
\hline 16 & none & $\begin{array}{l}\mathrm{HOF} \cdot \mathrm{MeCN} ; \mathrm{CH}_{2} \mathrm{Cl}_{2} \text {, flow } \\
\text { conditions }\end{array}$ & $\mathrm{ArNH}_{2}$ and $\mathrm{AlkNH}_{2}$ & - & [81] \\
\hline 17 & none & $\begin{array}{c}\mathrm{R}_{4} \mathrm{~N}^{+} \mathrm{BrO}_{3}^{-} ; \mathrm{CH}_{3} \mathrm{CO}_{2} \mathrm{H} \\
\mathrm{H}_{2} \mathrm{SO}_{4}, \text { reflux }\end{array}$ & $\begin{array}{l}\text { Electron-rich and } \\
\text { electron-poor } \mathrm{ArNH}_{2}\end{array}$ & - & [84] \\
\hline
\end{tabular}

However, broad though the developed routes are, some challenges remain. Further studies on the synthesis of heteroaryl nitro compounds via oxidation strategies would be desirable. Additionally, the development of selective procedures for the synthesis of amino-substituted nitroarenes represents a fascinating, yet difficult task. The investigation of the regiochemistry of the oxidation of diamines and polyamines under different reaction conditions is therefore an interesting research field.

On the other hand, additional efforts towards the development of additional catalysed, mild, environmentally benign protocols for the synthesis of nitro derivatives bearing valuable labile functional groups are needed. The environmental sustainability of processes is likely to attract growing attention. While catalyst recovery and recycling have been investigated and optimised, the purification of reaction products often relies on column chromatography, with the consequent use of large volumes of organic solvents and the production of significant amounts of solid waste.

Ideally, oxidation-based strategies could provide a versatile alternative for the synthesis of those chemicals that would be difficult to prepare through nitration methodologies.

Author Contributions: A.C. and D.T. conceptualised and wrote the manuscript. All authors have read and agreed to the published version of the manuscript.

Funding: This research received no external funding.

Data Availability Statement: Not applicable.

Acknowledgments: We thank MIUR-Italy (Progetto Dipartimenti di Eccellenza 2018-2022 allocated to Department of Chemistry "Ugo Schiff").

Conflicts of Interest: The authors declare no conflict of interest.

\section{References}

1. Ono, N. The Nitro Group in Organic Synthesis; Wiley-VCH: New York, NY, USA, 2001.

2. Muller, W.E. The Benzodiazepine Receptor; Cambridge University Press: New York, NY, USA, 1988.

3. Belciug, M.; Ananthanarayanan, V.S. Interaction of calcium channel antagonists with calcium: Structural studies on nicardipine and its $\mathrm{Ca}^{2+}$ complex. J. Med. Chem. 1994, 37, 4392-4399. [CrossRef] [PubMed]

4. Zollinger, H. Color Chemistry; Wiley-VCH: New York, NY, USA, 1987.

5. Koh, J.; Kim, S.; Kim, J.P. Synthesis and spectral properties of azohydroxypyridone disperse dyes containing a fluorosulphonyl group. Color. Technol. 2004, 120, 241-246. [CrossRef]

6. Fan, F.-R.F.; Yao, Y.; Cai, L.; Cheng, L.; Tour, J.M.; Bard, A.J. Structure-dependent charge transport and storage in self-assembled monolayers of compounds of interest in molecular electronics: Effects of tip material, headgroup, and surface concentration. J. Am. Chem. Soc. 2004, 126, 4035-4042. [CrossRef] [PubMed]

7. Luckenbach, T.; Epel, D. Nitromusk and polycyclic musk compounds as long-term inhibitors of cellular xenobiotic defense systems mediated by multidrug transporters. Environ. Health Perspect. 2005, 113, 17-24. [CrossRef]

8. Kresken, M.; Körber-Irrgang, B. In vitro activity of nitroxoline against escherichia coli urine isolates from outpatient departments in Germany. Antimicrob. Agents Chemother. 2014, 58, 7019-7020. [CrossRef]

9. Singha, P.; Locklin, J.; Handa, H. A review of the recent advances in antimicrobial coatings for urinary catheters. Acta Biomater. 2017, 50, 20-40. [CrossRef]

10. Townson, S.M.; Boreham, P.F.L.; Upcroft, P.; Upcroft, J.A. Resistance to the nitroheterocyclic drugs. Acta Trop. 1994, 56, 173-194. [CrossRef]

11. Muller, A.E.; Verhaegh, E.M.; Harbarth, S.; Mouton, J.W.; Huttner, A. Nitrofurantoin's efficacy and safety as prophylaxis for urinary tract infections: A systematic review of the literature and meta-analysis of controlled trials. Clin. Microbiol. Infect. 2017, 23, 355-362. [CrossRef] 
12. Rebstock, M.C.; Crooks, H.M.; Controulis, J.; Bartz, Q.R. Chloramphenicol (chloromycetin). IV. Chemical studies. J. Am. Chem. Soc. 1949, 71, 2458-2462. [CrossRef]

13. Olah, G.A.; Malhorta, R.; Narang, S.C. Nitration: Methods and Mechanisms; VCH: New York, NY, USA, 1989.

14. Yan, G.; Yang, M. Recent advances in the synthesis of aromatic nitro compounds. Org. Biomol. Chem. 2013, 11, 2554-2566. [CrossRef]

15. Weissermel, K.; Arpe, H.-J. Industrial Organic Chemistry; Wiley-VCH: Weinheim, Germany, 2008.

16. Prakash, G.K.S.; Mathew, T. ipso-Nitration of arenes. Angew. Chem. Int. Ed. 2010, 49, 1726-1728. [CrossRef]

17. D'Ans, J.; Kneip, A. Über organische Persäuren. Ber. Dtsch. Chem. Ges. 1915, 48, 1144. [CrossRef]

18. Bamberger, E.; Seligman, R. Oxydation aliphatischer Amine vom Typus >CH.NH2. Chem. Ber. 1903, 36, 701-710. [CrossRef]

19. Emmons, W.D. The oxidation of amines with peracetic acid. J. Am. Chem. Soc. 1957, 79, 5528-5530. [CrossRef]

20. Emmons, W.D. Peroxytrifluoroacetic acid. I. The oxidation of nitrosamines to nitramines. J. Am. Chem. Soc. 1954, 76, 3468-3470. [CrossRef]

21. Chambers, R.D.; Clark, M. Hexafluoroacetone-hydrogen peroxide, a new peroxyacid. Tetrahedron Lett. 1970, $32,2741-2742$. [CrossRef]

22. Gilbert, K.E.; Borden, W.T. Peracid oxidation of aliphatic amines: General synthesis of nitroalkanes. J. Org. Chem. 1979, 44, 659-661. [CrossRef]

23. Robinson, C.H.; Milewich, L.; Hofer, P. The oxidation of steroidal amines to nitro steroids. J. Org. Chem. 1966, 31, 524-528. [CrossRef]

24. Schwertfeger, H.; Würtele, C.; Schreiner, P.R. Synthesis of diamondoid nitro compounds from amines with $m$-chloroperbenzoic acid. Synlett 2010, 493-495. [CrossRef]

25. Liu, J.; Li, J.; Ren, J.; Zeng, B.-B. Oxidation of aromatic amines into nitroarenes with $m$-CPBA. Tetrahedron Lett. 2014, 55, 1581-1584. [CrossRef]

26. Meenakshi, R.; Shakeela, K.; Kutti Rani, S.; Ranga Rao, G. Oxidation of aniline to nitrobenzene catalysed by 1-Butyl-3-methyl imidazolium phosphotungstate hybrid material using m-chloroperbenzoic acid as an oxidant. Catal. Lett. 2018, 148, $246-257$. [CrossRef]

27. Yamaguchi, K.; Yoshida, C.; Uchida, S.; Mizuno, N. Peroxotungstate immobilized on ionic liquid-modified silica as a heterogeneous epoxidation catalyst with hydrogen peroxide. J. Am. Chem. Soc. 2005, 127, 530-531. [CrossRef]

28. Ramalingam, M.; Manickam, S.; Srinivasalu, K.R.; Ismail, M.B.; Deivanayagam, E. Ionic immobilization of silicotungstic acid on amine-functionalized zirconia: A mesoporous catalyst for esterification of maleic acid. Eur. J. Inorg. Chem. 2016, 11, 1697-1705. [CrossRef]

29. Patil, V.V.; Shankarling, G.S. Steric-hindrance-induced regio- and chemoselective oxidation of aromatic amines. J. Org. Chem. 2015, 80, 7876-7883. [CrossRef]

30. Ke, Q.; Wu, M.; Yu, H.; Lu, G. Superior catalytic performance of hierarchically micro-meso-macroporous CuAlPO-5 for the oxidation of aromatic amines under mild conditions. Chem. Cat. Chem. 2017, 9, 733-737. [CrossRef]

31. Jayachandran, B.; Sasidharan, M.; Sudalai, A.; Ravindranathan, T. Chromium silicalite-2 (CrS-2): An efficient catalyst for the direct oxidation of primary amines to nitro compounds with TBHP. J. Chem. Soc. Chem. Commun. 1995, 15, 1523-1524. [CrossRef]

32. Ratnikov, M.O.; Farkas, L.E.; McLaughlin, E.C.; Chiou, G.; Choi, H.; El-Khalafy, S.H.; Doyle, M.P. Dirhodium-catalyzed phenol and aniline oxidations with T-HYDRO. Substrate scope and mechanism of oxidation. J. Org. Chem. 2011, 76, 2585-2593. [CrossRef]

33. Tollari, S.; Vergani, D.; Banfi, S.; Porta, F. Oxidation of primary aromatic amines to nitro derivatives catalysed by iron(III) and manganese(III) tetraaryl porphyrins. J. Chem. Soc. Chem. Commun. 1993, 5, 442-444. [CrossRef]

34. Krohn, K.; Kiipke, J.; Rieger, H. Zirkonium-katalysierte oxidation von primären aromatischen aminen zu nitroverbindungen mit tert-butylhydroperoxid. J. Prakt. Chem. Chem.-Ztg. 1997, 339, 335-339. [CrossRef]

35. Reddy, K.R.; Maheswari, C.U.; Venkateshwar, M.; Kantam, M.L. Selective oxidation of aromatic amines to nitro derivatives using potassium iodide-tert-butyl hydroperoxide catalytic system. Adv. Synth. Catal. 2009, 351, 93-96. [CrossRef]

36. Dewkar, G.K.; Nikalje, M.D.; Sayyed Ali, I.; Paraskar, A.S.; Jagtap, H.S.; Sudalai, A. An exceptionally stable ti superoxide radical ion: A novel heterogeneous catalyst for the direct conversion of aromatic primary amines to nitro compounds. Angew. Chem. Int. Ed. 2001, 40, 405-408. [CrossRef]

37. Tressler, C.M.; Stonehouse, P.; Kyler, K.S. Calcium tungstate: A convenient recoverable catalyst for hydrogen peroxide oxidation. Green Chem. 2016, 18, 4875-4878. [CrossRef]

38. Sakaue, S.; Tsubakino, T.; Nishiyama, Y.; Ishii, Y. Oxidation of aromatic amines with hydrogen peroxide catalyzed by cetylpyridinium heteropolyoxometalates. J. Org. Chem. 1993, 58, 3633-3638. [CrossRef]

39. Tabatabaee, M.; Hashemian, S.; Roozbeh, M.; Roozbeh, M.; Mirjalili, M. Lacunary Keggin-type heteropolyanion, $\alpha-$ $\left[\mathrm{PMo}_{2} \mathrm{~W}_{9} \mathrm{O}_{39}\right]^{7-}$, as an efficient homogenous catalyst for oxidation of aromatic amines. Res. Chem. Intermed. 2015, 41, 231-234. [CrossRef]

40. Tundo, P.; Romanelli, G.P.; Vázquez, P.G.; Loris, A.; Aricò, F. Multiphase oxidation of aniline to nitrosobenzene with hydrogen peroxide catalyzed by heteropolyacids. Synlett 2008, 967-970. [CrossRef]

41. Sloboda-Rozner, D.; Witte, P.; Alsters, P.L.; Neumann, R. Aqueous biphasic oxidation: A water-soluble polyoxometalate catalyst for selective oxidation of various functional groups with hydrogen peroxide. Adv. Synth. Catal. 2004, 346, 339-345. [CrossRef] 
42. Defoin, A. Simple preparation of nitroso benzenes and nitro benzenes by oxidation of anilines with $\mathrm{H}_{2} \mathrm{O}_{2}$ catalysed with molybdenum salts. Synthesis 2004, 5, 706-710. [CrossRef]

43. Voutyritsa, E.; Theodorou, A.; Kokotou, M.G.; Kokotos, C.G. Organocatalytic oxidation of substituted anilines to azoxybenzenes and nitro compounds: Mechanistic studies excluding the involvement of a dioxirane intermediate. Green Chem. 2017, 19, 1291-1298. [CrossRef]

44. Gupta, S.; Ansari, A.; Sashidhara, K.V. Base promoted peroxide systems for the efficient synthesis of nitroarenes and benzamides. Tetrahedron Lett. 2019, 60, 151076. [CrossRef]

45. Neimann, K.; Neumann, R. A new non-metal heterogeneous catalyst for the activation of hydrogen peroxide: A perfluorinated ketone attached to silica for oxidation of aromatic amines and alkenes. Chem. Commun. 2001, 5, 487-488. [CrossRef]

46. Lenardão, E.J.; Santi, C.; Sancineto, L. New Frontiers in Organoselenium Compounds; Springer: Gewerbestrasse, Switzerland, 2018.

47. Singh, F.V.; Wirth, T. Organoselenium Chemistry. Synthesis and Reactions; Wirth, T., Ed.; Wiley-VCH: Weinheim, Germany, 2012; Chapter 8.

48. Rathore, V.; Jose, C.; Kumar, S. Organoselenium small molecules as catalysts for the oxidative functionalization of organic molecules. New J. Chem. 2019, 43, 8852-8864. [CrossRef]

49. Młochowski, J.; Wójtowicz-Młochowska, H. Developments in synthetic application of selenium(IV) oxide and organoselenium compounds as oxygen donors and oxygen-transfer agents. Molecules 2015, 20, 10205-10243. [CrossRef]

50. Młochowski, J.; Brząszcz, M.; Giurg, M.; Palus, J.; Wójtowicz, H. Selenium-promoted oxidation of organic compounds: Reactions and mechanisms. Eur. J. Org. Chem. 2003, 4329-4339. [CrossRef]

51. Yu, L.; Wang, J.; Chen, T.; Wang, Y.; Xu, Q. Recyclable 1,2-bis[3,5-bis(trifluoromethyl)phenyl]diselane-catalyzed oxidation of cyclohexene with $\mathrm{H}_{2} \mathrm{O}_{2}$ : A practical access to trans-1,2-cyclohexanediol. Appl. Organomet. Chem. 2014, 28, 652-656. [CrossRef]

52. Jensen, H.P.; Sharpless, K.B. Selenium dioxide oxidation of d-limonene. Reinvestigation. J. Org. Chem. 1975, 40, $264-265$. [CrossRef]

53. Back, T.G. Oxidation of azasteroid lactams and alcohols with benzeneseleninic anhydride. J. Org. Chem. 1981, 46, 1442-1446. [CrossRef]

54. Capperucci, A.; Petrucci, A.; Faggi, C.; Tanini, D. Click reaction of selenols with isocyanates: Rapid access to selenocarbamates as peroxide-switchable reservoir of thiol-peroxidase-like catalysts. Adv. Sinth. Catal. 2021, 363, 4256-4263. [CrossRef]

55. Arai, K.; Sato, Y.; Nakajima, I.; Saito, M.; Sasaki, M.; Kanamori, A.; Iwaoka, M. Glutathione peroxidase-like functions of 1, 2-diselenane-4, 5-diol and its amphiphilic derivatives: Switchable catalytic cycles depending on peroxide substrates. Bioorg. Med. Chem. 2021, 29, 115866. [CrossRef]

56. Tanini, D.; Capperucci, A. Synthesis and applications of organic selenols. Adv. Synth. Catal. 2021, 363, 5360-5385. [CrossRef]

57. Tanini, D.; Lupori, B.; Malevolti, G.; Ambrosi, M.; Lo Nostro, P.; Capperucci, A. Direct biocatalysed synthesis of first sulfur-, selenium- and tellurium- containing L-ascorbyl hybrid derivatives with radical trapping and GPx-like properties. Chem.Commun. 2019, 55, 5705-5708. [CrossRef]

58. Sands, K.N.; Tuck, T.A.; Back, T.G. Cyclic Seleninate esters, spirodioxyselenuranes and related compounds: New classes of biological antioxidants that emulate glutathione peroxidase. Chem. Eur. J. 2018, 24, 9714-9728. [CrossRef]

59. Tanini, D.; Grechi, A.; Ricci, L.; Dei, S.; Teodori, E.; Capperucci, A. Novel functionalized organotellurides with enhanced thiol peroxidase catalytic activity. New J. Chem. 2018, 42, 6077-6083. [CrossRef]

60. Kumakura, F.; Mishra, B.; Priyadarsini, K.I.; Iwaoka, M. A watersoluble cyclic selenide with enhanced glutathione peroxidase-like catalytic activities. Eur. J. Org. Chem. 2010, 3, 440-445. [CrossRef]

61. Mugesh, G.; Singh, H.B. Synthetic organoselenium compounds as antioxidants: Glutathione peroxidase activity. Chem. Soc. Rev. 2000, 29, 347-357. [CrossRef]

62. Tanini, D.; Dalia, C.; Capperucci, A. The polyhedral nature of selenium-catalysed reactions: Se(IV) species instead of Se(VI) species make the difference in the on water selenium-mediated oxidation of arylamines. Green Chem. 2021, 23, 5680-5686. [CrossRef]

63. Zhao, D.; Johansson, M.; Bäckvall, J.-E. In situ generation of nitroso compounds from catalytic hydrogen peroxide oxidation of primary aromatic amines and their one-pot use in hetero-diels-alder reactions. Eur. J. Org. Chem. 2007, 4431-4436. [CrossRef]

64. Priewisch, G.B.; Irran, E.; Rück-Braun, K. Oxidation of anilines with hydrogen peroxide and selenium dioxide as catalyst. Synthesis 2008, 12, 1889-1894.

65. Sands, K.N.; Rengifo, E.M.; George, G.N.; Pickering, I.J.; Gelfand, B.S.; Back, T.G. The unexpected role of se ${ }^{\mathrm{vi}}$ species in epoxidations with benzeneseleninic acid and hydrogen peroxide. Angew. Chem. Int. Ed. 2020, 59, 4283-4287. [CrossRef]

66. Marinescu, L.G.; Doyagüez, E.G.; Petrilli, M.; Fernández-Mayoralas, A.; Bols, M. Amino-acetone-bridged cyclodextrins-Artificial alcohol oxidases. Eur. J. Org. Chem. 2010, 157-167. [CrossRef]

67. Marinescu, L.; Mølbach, M.; Rousseau, C.; Bols, M. Supramolecular oxidation of anilines using hydrogen peroxide as stoichiometric oxidant. J. Am. Chem. Soc. 2005, 127, 17578-17579. [CrossRef]

68. McKillop, A.; Tarbin, J.A. Sodium perborate-A cheap and effective reagent for the oxidation of anilines and sulphides. Tetrahedron Lett. 1983, 24, 1505-1508. [CrossRef]

69. Firouzabadi, H.; Iranpoor, N.; Amani, K. Tungstophosphoric acid catalyzed oxidation of aromatic amines to nitro compounds with sodium perborate in micellar media. Green Chem. 2001, 3, 131-132. [CrossRef] 
70. Habibi, D.; Zolfigol, M.A.; Safaiee, M. Silica sulphuric acid as an efficient catalyst for the catalytic and metal-free oxidation of aromatic amines to their corresponding nitro compounds with sodium perborate under micellar media. S. Afr. J. Chem. 2008, 61, 93-96.

71. Murray, R.W.; Jeyaraman, H.; Mohan, L. A new synthesis of nitro compounds using dimethyldioxirane. Tetrahedron Lett. 1986, 27, 2335-2336. [CrossRef]

72. Murray, R.W.; Rajadhyaksha, S.N.; Mohan, L. Oxidation of primary amines by dimethyldioxirane. J. Org. Chem. 1989, 54, 5783-5788. [CrossRef]

73. Murray, R.W.; Jeyaraman, H. Dioxiranes: Synthesis and reactions of methyldioxiranes. J. Org. Chem. 1985, 50, 2847-2853. [CrossRef]

74. Zabrowski, D.L.; Moormann, A.E.; Beck, K.R. The oxidation of aromatic amines in the presence of "electron-rich" aromatic systems. Tetrahedron Lett. 1988, 29, 4501-4504. [CrossRef]

75. Webb, K.S.; Seneviratne, V. A Mild oxidation of aromatic amines. Tetrahedron Lett. 1995, 36, 2377-2378. [CrossRef]

76. Shiney, A.; Rajan, P.K.; Sreekumar, K. Polystyrene-bound dioxirane: A new class of recyclable oxidising reagent. Polym. Int. 1996, 41, 377-381. [CrossRef]

77. Vázquez Sánchez, A.; Ávila Zárraga, J.G. Green oxidation of organic compounds: Manganese sulphate/oxone ${ }^{\circledR} /$ water. J. Mex. Chem. Soc. 2007, 51, 213-216.

78. Golan, E.; Rozen, S. A Fast, high-yield preparation of vicinal dinitro compounds using $\mathrm{HOF}, \mathrm{CH}_{3} \mathrm{CN}$. J. Org. Chem. 2003, 68, 9170-9172. [CrossRef]

79. Kol, M.; Rozen, S. Oxidizing aromatic amines to nitroarenes with the HOF-MeCN system. J. Chem. Soc. Chem. Commun. 1991, 567-568. [CrossRef]

80. Rozen, S.; Bar-Haim, A.; Mishani, E. New efficient route to $\alpha$-nitro acids. Oxidation of amino acids with $\mathrm{HOF}^{\mathrm{C}} \mathrm{CH}_{3} \mathrm{CN}$. J. Org. Chem. 1994, 59, 1208-1209. [CrossRef]

81. McPake, C.B.; Murray, C.B.; Sandford, G. Sequential continuous flow processes for the oxidation of amines and azides by using HOF.MeCN. ChemSusChem 2012, 5, 312-319. [CrossRef]

82. Joshaghani, M.; Bahadori, M.; Rafiee, E.; Bagherzadeh, M. Oxidative transformation of organic compounds using bis(bipyridine)silver(II) peroxydisulfate. Arkivoc 2007, 16, 260-265. [CrossRef]

83. Joshaghani, M.; Bahadori, M.; Rafiee, E.; Bagherzadeh, M. Oxidative transformation of organic compounds using bis(1,10phenanthroline)silver(II) peroxydisulfate as a twin catalyst/oxidant. J. Iran. Chem. Soc. 2008, 5, S108-S112. [CrossRef]

84. Das, S.S.; Nath, U.; Deb, D.; Das, P.J. A Convenient method for the oxidation of aromatic amines to nitro compounds using tetra-n-alkylammonium bromates. Synth. Commun. 2004, 34, 2359-2363. [CrossRef] 